\title{
APPLYING ANTITRUST LAW TO COLLABORATION IN THE PRODUCTION OF INFORMATION: THE CASE OF MEDICAL TECHNOLOGY ASSESSMENT
}

\author{
Clark C. Havighurst*
}

I

\section{INTRODUCTION}

Efficiency in the provision of medical services depends heavily upon the availability to consumers and their various agents of information concerning the safety, efficacy, and cost-effectiveness of particular methods of diagnosis and treatment. Unfortunately, information of this kind tends to be a public good that can be widely shared by free riders who pay nothing toward the cost of its production.' To the extent, then, that society relies upon private producers and market incentives to yield information concerning medical treatments and other health care technology, it will be disappointed in the amount and quality of the information produced. Society will be doubly disappointed, however, if courts administering the nation's antitrust laws fail to appreciate that efforts by industry groups to gather, generate, or disseminate such information are a highly "procompetitive" form of competitor collaboration and therefore deserve some protection against legal attacks by other competitors whom the information happens to hurt. This article seeks to clarify the antitrust status of organizations of professional competitors that engage in the evaluation of medical technologies.

The danger that antitrust litigation might chill technology assessment in medicine and thus sacrifice efficiency is not merely a theoretical risk. Two antitrust suits have challenged one instance of professional involvement in the evaluation of a new medical technology, ${ }^{2}$ occasioning concern in scientific and professional circles. ${ }^{3}$ These cases arose out of efforts by members of the American Academy of Ophthalmology, Inc. ("AAO"), to impede what they

Copyright $(1989$ by Law and Contemporary Problems

* William Neal Reynolds Professor of Law, Duke University. This article reflects work supported by Grant No. HS 04089 from the National Center for Health Services Research and Health Care Technology Assessment, U.S. Department of Health and Human Services.

1. See infra notes 31-34 and accompanying text.

2. Schachar v. American Academy of Ophthalmology, Inc. 870 F.2d 397 (7th Cir. 1989); Vest v. Waring, 565 F. Supp. 674 (N.D. Ga. 1983).

3. See, e.g., Ross \& Leibenluft, Antitrust Implications of Medical Technology Assessment, 314 N. ENG. J. MED. 1490 (1986); Norman, Clinical Trial Stirs Legal Battle, 227 Scr. 1316 (1985). 
purported to believe was too-ready acceptance in medical practice of radial keratotomy, a revolutionary but unproven surgical technique for correcting nearsightedness. ${ }^{4}$ The plaintiffs, including both practicing eye surgeons and patients, alleged that certain academic ophthalmologists had conspired to "monopolize" the procedure by inducing influential professional organizations to issue advisory statements to the effect that the new surgical procedure, not having passed the threshold of scientific acceptability, was still "experimental." Allegedly, this action caused health insurers and other payers to refuse to cover the procedure ${ }^{5}$ and induced hospitals to limit its use. $^{6}$ At the same time, the defendants had organized, and obtained federal funding for, a rigorous clinical trial of the procedure at nine academic medical centers. The plaintiffs alleged that this study, together with other activities of the defendants, made it difficult for anyone to undertake or undergo the procedure under any other auspices.

The plaintiffs in the second of the radial keratotomy cases, ${ }^{7}$ Schachar $v$. $A A O$, survived a motion for summary judgment in 1988 because, in the district court's view, "the statements and conduct of defendants . . . have a coercive economic influence in the field of ophthalmology." 8 If such cases were indeed to turn on the somewhat oxymoronic notion of "coercive . . . influence," a prestigious professional organization would risk liability for treble damages whenever it expressed a persuasive opinion unfavorable to those seeking to market a particular technology. Moreover, if such an organization sponsored a clinical trial in an effort to elicit new scientific information, it would run the additional risk that the methods by which it encouraged practitioners to participate in the trial or the restrictions that it imposed on them to ensure the trial's scientific validity might be characterized as "restraints of trade,"'9 triggering liability. If such legal risks should inhibit professional bodies from expressing their collective views on technology issues or participating in the development of new knowledge, the public would be forced to purchase medical services in unnecessary ignorance.

4. A comparable procedure for correcting farsightedness, also developed by a Soviet eye surgeon, is presenting comparable questions today. Van, U.S. Surgeons Cautious on Moscow Farsightedness Operation, Durham Morning Herald, Mar. 26, 1989, at D11, col. 1.

5. Authoritative statements concerning the state of scientific knowledge can influence the construction of statutes and insurance policies governing the obligations of public and private payers for medical care, who are generally not required to pay for a treatment that is not yet medically recognized. Many payers, apparently taking their cue from the opinions of radial keratotomy so authoritatively expressed and from the use of the magical word "experimental," refused to pay for the procedure until it had been somehow validated by the medical/academic complex.

6. Hospitals were apparently influenced not only by the difficulty of obtaining payment but also by doubts about the legal risks and ethics of allowing experimental surgery on their premises.

7. The first case was settled inconclusively following a 1983 ruling on certain immunity and jurisdictional issues. Vest v. Waring, 565 F. Supp. 674 (N.D. Ga. 1983). See Suit Against PERK Ophthalmologists Is Settled, Ocular Surgery News, Aug. 1, 1985, at 1 (reporting settlement and setting forth one defendant's new, favorable opinion of radial keretotomy, the issuance of which was required by terms of settlement).

8. 1988-1 Trade Cas. (CCH) ๆ 67, 986, at 58,053 (N.D. Ill. 1988).

9. Section 1 of the Sherman Act prohibits "[e]very contract, combination ..., or conspiracy, in restraint of trade . . ." 15 U.S.C. $\$ 1$ (1983). 
Because information of this kind is in short supply in any event, undue legal constraints on its collective production and dissemination could be quite costly to society in its attempt to avoid unwise spending on health services.

Fortunately, the Schachar case was finally resolved in a way that should allay some of the fears to which it gave rise. Not only did the trial of the case result in a jury verdict for the defendants, but the Court of Appeals for the Seventh Circuit, in ruling on the plaintiffs' appeal, held that the case should never have been submitted to the jury in the first place. ${ }^{10}$ The court stated that "when a trade association provides information . . . but does not constrain others to follow its recommendations, it does not violate the antitrust laws." 11 The court also expressed impatience toward the plaintiffs' theory that an expression of a collective opinion can, without more, restrain trade:

Antitrust law does not compel your competitor to praise your product . . . Unless one group of suppliers diminishes another's ability to peddle its wares (technically, reduces rivals' elasticity of supply), there is not even the beginning of an antitrust case, no reason to investigate further to determine whether the restraint is "reasonable."12

Judge Easterbrook, writing for the court, began his opinion by stating that the case was decided by the "truism" that "there can be no restraint of trade without a restraint."13

Although Judge Easterbrook's incisiveness is refreshing, his opinion in Schachar leaves some possible questions unaddressed. Moreover, his reputation as an exponent of the "Chicago School" of antitrust theorizing ${ }^{14}$ may cause some observers to discount his hard-line rhetoric-for example, "we do not perceive what this has to do with antitrust"15 - and to cling to traditional theories of antitrust law that might provide relief in another case or in another circuit. ${ }^{16}$ At the risk of dignifying some such legal theories more than they deserve, this article seeks to provide a somewhat broader foundation for the Schachar court's ruling and to explore some issues that the case did not directly raise. It begins by providing some background on the economics and policy implications of medical technology assessment.

\section{II}

\section{The Market for Information Concerning Medical TECHNOLOGIES}

Medical science has always been dedicated to discovering safe and efficacious ways of treating disease, and the medical profession has always

10. 870 F.2d. at 398 .

11. Id. at 399.

12. Id. Presumably the court meant directly "diminishes another's ability...." See infra notes 86, 87 and accompanying text.

13. Id. at 397.

14. Judge Easterbrook, a former law professor at the University of Chicago, has been a leader in the rethinking of antitrust policy that has occurred in the past decade. See, e.g., Easterbrook, Workable Antitrust Policy, 84 Mich. L. Rev. 1696 (1986); Easterbrook, The Limits of Antitrust, 63 Tex. L. Rev. 1 (1984). On the larger movement, see infra notes 120-21.

15. 870 F.2d at 400 .

16. See infra note 121 . 
portrayed itself as the exclusive vehicle for translating scientific learning into benefits for patients. Major questions have been raised in recent years, however, about the quality and completeness of scientific inquiry by medical researchers, about the scientific evidence supporting many of physicians' customary practices, and about the process by which technologies enter into, or are retained in, the mainstream of medical care. It has been pointed out, for example, that many diagnostic and treatment procedures in widespread use are not known with adequate certainty to benefit patients, either at all or under many of the circumstances in which they are employed. ${ }^{17}$ Even when there is a basis for believing in the efficacy of a particular technology, it may not be known whether alternative methods are better at achieving the desired result in at least some circumstances or whether they are capable of doing so at a lower cost or with less risk of significant side effects. There are, indeed, several rather startling findings concerning the weakness of the scientific evidence supporting some widely accepted medical treatments. ${ }^{18}$ The absence of clear scientific guidance has contributed to wide variations in physicians' clinical practices. ${ }^{19}$

Critics of medical science and medical practice have had excellent success in stimulating interest in technology assessment in the 1980's. Indeed, both public and private decision makers have become quite enamored of the concept. ${ }^{20}$ In general, medical technology assessment might be thought of as

17. E.g., B. Jennett, High Technology Medicine: Benefits and Burdens $221-26$ (1986); A. Cochrane, Effectiveness and Efficiency: Random Reflections on Health Services 27-44 (1971); Eddy \& Billings, The Quality of Medical Evidence: Implications for Quality of Care, HEALTH AFFS., Spring 1988, at 19, 20 ("for at least some important practices, the existing evidence is of such poor quality that it is virtually impossible to determine even what effect the practice has on patients, much less whether that effect is preferable to the outcomes that would have occurred with other options"); Eddy, Clinical Policies and the Quality of Clinical Practice, 307 NEw ENG. J. MEd. 343 (1982) ("there is reason to believe that there are flaws in the process by which the profession generates clinical policies").

The Schachar court observed the need for technology assessment as follows:

Even the most promising medical developments often turn out to have drawbacks, whose nature and magnitude should be determined. Many who have undergone radial keratotomy report improvement in their eyesight (sometimes so much change that they become farsighted). What are the long-run consequences? Most persons' visual acuity slowly changes with time. Does the eyesight of those who have had this operation change in different ways? Might the invasive procedure weaken the eye in a way that creates problems of a different kind? A surgical procedure used in Japan in the 1950s caused "corneal decompensation" about ten years later, a serious condition leading to blindness (avoidable with corneal transplants). Radial keratotomy is different, but once burned twice shy.

870 F.2d at 398.

18. See, e.g., A. Cochrane, supra note 17, at 45-66; Eddy \& Billings, supra note 17; Eddy, Sanders \& Eddy, The Value of Screening for Glaucoma with Tonometry, 28 Survey of OPhthalmolocy 194 (1983). See generally B. JENNETT, supra note 17, at 53-140.

19. E.g., Chassin, Brook, Park, Keesey, Fink, Kosecoff, Kahn, Merrick \& Solomon, Variations in the Use of Medical and Surgical Services by the Medicare Population, 314 NEw ENG. J. MEd. 285, 286-87 (1986); Wennberg, Dealing with Medical Practice Variations: A Proposal for Action, HeALth AfFs., Summer 1984, at 6, 7; Wennberg \& Gittelsohn, Small Area Variations in Health Care Delivery, 182 ScI. 1102 (1973).

20. See generally Institute of Medicine, Council on Health Care Technology, Medical Technology Assessment Directory: A Pilot Reference to Organizations, Assessments, and Information Resources (1988); Institute of Medicine, Assessing Medical Technologies (1985); 
the total process by which society decides-formally and informally, publicly and privately, well or poorly-on the appropriate uses of the various methods available for diagnosing or treating disease. In its current vogue, however, the notion of medical technology assessment contemplates specific public or private programs featuring at least one of two elements: "knowledge processing" (gathering, validating, interpreting, or disseminating existing data and insights) and "knowledge development" (the generation of new data and understanding through clinical trials, ethical and other assessments, and other means). ${ }^{21}$ The discussion here focuses first on the demand side of the market for formal assessments of medical technology, noting the increasing interest in technology questions in the 1980's. It then examines the supply side of that market, noting why there is an apparent shortage of such assessments, observing the arrangements that are being made to meet the unmet need, and finally arguing against letting the assessment of medical technologies be monopolized by either public or private suppliers of information. This background is essential to an appraisal of the effects on competition of technology assessments by professional organizations.

\section{A. The Demand for Medical Technology Assessment}

The increased interest in medical technology assessment in the 1980's has reflected concerns about both the quality and the cost of health care. Although quality and cost considerations sometimes point in opposite directions, better answers to many specific technology questions could have positive implications for both patient outcome and the cost of treatment. The growing enthusiasm for technology assessment is partly a response to this win/win potential as well as to the shortcomings of traditional medical institutions in screening for safety and efficacy. To a lesser extent, however, it may also reflect the reversal of a long-standing neglect in the health care industry of certain more controversial factors that should also influence medical decisions.

Until recently, safety and efficacy were thought to be the only issues that had to be resolved before a new technology could assume a place in the medical armamentarium. Neither the financing system, which was generally committed to pay for anything "medically necessary," nor medical ethics, which essentially ruled out economic considerations in medical decisionmaking, acknowledged the possible existence of tradeoffs between quality and cost. Although quality and cost objectives are not always inconsistent, there will be many situations in which a medical test or procedure that is undeniably safe and efficacious-in the sense that the probability of a net benefit to the patient's health is greater than .0-yields an expected incremental benefit that may not be great enough to warrant

L. Russell, Technology in Hospitals $132-55$ (1979); Foote, Assessing Medical Technology Assessment: Past, Present, and Future, 65 Milbank Q. 59 (1987).

21. Foote, supra note 20, at 60 (citing Blumenthal, Federal Policy toward Health Care Technology: The Case of the National Center, 61 Milbank MEm. Fund Q. 584, 589-592 (1983)). 
incurring its attendant cost. ${ }^{22}$ To be sure, such tradeoffs are frequently ignored in the belief that overall costs can be significantly reduced without compromising the quality of care. Nevertheless, quality/cost tradeoffs cannot be finessed indefinitely, despite everyone's understandable reluctance to place, even implicitly, a finite value on other persons' lives or health status. ${ }^{23}$ Whether or not the new demand for medical technology assessments is prompted in any measure by new interest in comparing marginal benefits with marginal costs, better data would greatly facilitate such comparisons if and when decisionmakers become prepared to face them.

Some of the new demand for medical technology assessment may reflect fundamental changes in the health care industry that have lessened previous tendencies to use costly technologies without good evidence of their worth. For example, a series of developments, including antitrust enforcement, have weakened the power of the organized medical profession to shape the delivery and financing of medical care according to the ideology and economic preferences of physicians. ${ }^{24}$ Under earlier arrangements, the quality of care was much honored by the profession as the sole desideratum in decisions on medical matters. Quality assurance was expected to flow, however, from paying individual practitioners on a fee-for-service basis and allowing them to exercise independent judgment without cost constraints. ${ }^{25}$ Left to their own devices in such a system, physicians were quite receptive to new technologies, even without convincing evidence of their benefits to particular patients. ${ }^{26}$

The most important impetus for the growth of high-tech medicine was third party financing, which underwrote physicians' propensities to use

22. See generally Schwartz \& Joskow, Medical Efficacy versus Economic Efficiency: A Conflict in Values, 299 New Eng. J. MEd. 1462 (1978); Havighurst \& Blumstein, Coping with Quality/Cost Trade-offs in Medical Care: The Role of Professional Standards Review Organizations, 70 Nw. U.L. REv. 6, 9-20 (1975). 38.

23. See Schwartz \& Joskow, supra note 22, at 1463; Havighurst \& Blumstein, supra note 22, at 9-

24. See generally Havighurst, The Changing Locus of Decision Making in the Health Care Sector, $11 \mathrm{~J}$. Health Pol. Pol'y \& L. 697 (1986).

25. To protect professional independence, the profession counselled against letting physicians become accountable to any lay-controlled agency-especially one, it seemed, that might represent the aggregate interests of consumers as purchasers. This professional attitude was embodied in an ethical canon against "contract practice," which was found unlawful by the FTC in AMA v. FTC, 638 F.2d 443 (2d Cir. 1980), aff'd by an equally divided Court, 455 U.S. 676 (1982). The legal system, not appreciating all that was at stake, tended to ratify the doctors' belief that corporate middlemen were inappropriate agents of the consumer by establishing a variety of prohibitions against the "corporate practice of medicine." See, e.g., Wiorek, The Corporate Practice of Medicine Doctrine: An Outmoded Theory in Need of Modification, 8 J. Legal MEd. 465 (1987); Note, The Corporate Practice of Medicine Doctrine: An Anachronism in the Modern Health Care Industry, 40 VAND. L. REv. 445 (1987).

26. See supra notes 17,18 . Despite their ostensibly scientific education, physicians were not fully prepared to evaluate critically the scientific studies published in medical journals or the claims of drug salesmen, nor were they adequately trained to distrust, on the ground of the smallness of the sample, their own clinical experience or their colleagues' anecdotes. Instead, physicians were quite ready to believe that anything they did, if sanctioned by published research and consistent with the practices of others, was helpful to their patients. Many believed, moreover, that physicians were motivated by a "technological imperative" that dictated doing something rather than nothing and more rather than less. E.g., V. Fuchs, Who Shall Live? 60, 95 (1974); Havighurst \& Blumstein, supra note 22, at 20-30 ("quality imperative"). The law of medical malpractice is widely thought to reinforce this propensity to omit nothing that might in retrospect be deemed potentially beneficial. 
resources without regard to social costs. The medical profession itself assiduously cultivated methods of financing care that expanded demand for medical services (by making virtually everything affordable) while omitting most of the controls that would be needed to offset the cost-increasing effects of "moral hazard." 27 Although the profession supplied peer-review bodies to resolve disputes about what should be paid for, the bias of professional peer reviewers in favor of practitioner independence and against cost containment left physicians with wide discretion. ${ }^{28}$ In general, the old medical care financing system lacked both reliable administrative checks on the adoption of new technologies and incentives to discourage inefficient use of resources. ${ }^{29}$

In recent years and especially in the 1980's, public and private payers for medical care have become increasingly concerned about costs and have finally found ways to give effect to their concerns. In particular, they have moved away from compensating providers in the ways that providers themselves prefer. Thus, fee-for-service payments to professionals and retrospective cost reimbursement to institutions are being replaced by various forms of "prospective payment"-fixed allowances for treating a given condition, a given patient, or a given population. These initiatives on the part of payers have changed providers' incentives in ways that encourage some economizing. At the same time, quality-of-care concerns, heightened by rising malpractice claims as well as by fears that new incentives might prompt overeconomizing, have appeared on the purchasers' side of the market in the form of a desire to ensure that value is being received for money.

In general, the current market for health care services features somewhat more skepticism than previously prevailed toward physicians' unconstrained choices of treatment. Government programs have moved increasingly to scrutinize and second-guess physician decisions in the interest of both improved quality and cost containment. Similar skepticism has also begun to appear in the private sector, where various consumer agents-individual physicians, hospitals, HMO's, employers, insurers, and others-are tentatively approaching the difficult task of weighing the benefits of particular medical services against both the opportunity costs (alternatives forgone) and the dollar costs thereof. The demand for more information useful in making the necessary public and private judgments accounts for some of the new interest in medical technology assessment.

27. This is the term used by economists for the natural tendency of people to suspend normal economizing whenever they are in a position, because of insurance or otherwise, to risk or spend another's funds. See P. Joskow, Controlling Hospital Costs: The Role of Government REGulation 21-31 (1981). On professional efforts to foster preferred methods of financing, see Havighurst, Professional Restraints on Innovation in Health Care Financing, 1978 DukE L.J. 303; Goldberg \& Greenberg, The Effect of Physician-Controlled Health Insurance: U.S. v. Oregon State Medical Society, $2 \mathrm{~J}$. Health Pol. Pol'y \& L. 48 (1977).

28. See generally Havighurst, Professional Peer Review and the Antitrust Laws, 30 CASE W. RES. L. REv. 1117 (1986); Havighurst \& Blumstein, supra note 22, at 25-68.

29. See generally Havighurst, The Questionable Cost-Containment Record of Commercial Health Insurers, in Health Care in America 221 (H. Frech ed. 1988). 


\section{B. The Supply of Technology Assessments}

The recent increase in the demand for sophisticated technology assessments seems not to have been met by a commensurate increase in the supply of such assessments. ${ }^{30}$ Part of the problem lies in a fundamental failure in the market mechanism that might ordinarily be expected to call forth supply to meet new demand. Despite the great social value of information concerning medical technologies, severe free-rider problems make it impossible to count upon private entrepreneurs to produce the optimal quantity of such information. The shortfall in the private production of medical technology assessments reflects the fact that information is a "public good."31

Like other public goods, information is not consumed when it is used. Unlike ordinary goods or services, which are purchased and used in varying quantities, a buyer of information can make extensive use of it while paying for it only once. He may also make it available to others, thus undercutting the ability of its originator to recover its production costs by marketing it at a price reflecting its value. ${ }^{32}$ Although copyright protection inhibiting copying and other free riding might sometimes be obtainable, copyright infringements are difficult to detect and police, especially if there are more than a handful of users. In any event, a free rider might simply bide his time until he could imitate the conduct of those who had access to proprietary information. ${ }^{33}$ Ease of imitation, as well as ease of access, reduces the incentive for private production. ${ }^{34}$

Because public goods will be underproduced under market incentives, special social arrangements are necessary if output is to approach the optimal level. The special arrangements for producing information concerning medical technology include all the institutions of medical science. Medical research, both basic and clinical, is carried out for the most part by nonprofit institutions and is largely financed by public and philanthropic funds. Moreover, it relies upon the scientific tradition of treating research findings as communal property; free sharing of information allows each researcher to build upon the work of others and benefits anyone else to whom the information is useful. Although medical research in such fields as pharmaceuticals, medical devices, and genetic engineering is carried out for

30. There has, however, been a considerable outpouring of assessments. See generally INSTITUTE of Medicine, Council on Health Care Technology, Medical Technology Assessment Directory, supra note 20.

31. For a discussion of the distinction between private and public goods and the economic problems connected with the latter, see R. COOTER \& T. ULEN, LAW AND EConomics 108-12 (1988).

32. Similarly, a producer seeking to market information will find it difficult to practice profitmaximizing price discrimination-that is, to charge buyers different prices based on the probable value of the information to each. Not only could a buyer of information supply it to others while also using it intensively himself, but arbitragers, posing as light or marginal users, could purchase the information cheap and resell it to others.

33. For example, a health insurer might simply conform its coverage of new technologies to that of larger, better informed payers, such as Blue Cross/Blue Shield plans.

34. See Havighurst, supra note 29 , at 238-40. 
profit with patent protection available to frustrate would-be free riders, a great deal of additional research, including the independent evaluation of patented technologies, is of a nonproprietary character. Public and nonprofit sponsorship of such research is a direct reflection not only of the difficulty of effectively protecting and marketing intellectual property but of the social inefficiency, once research findings (and any other public goods) are produced, of excluding anyone from using them.

Because traditional medical research is heavily supported by public funds, public policy makers have been increasingly able to direct the efforts of the scientific establishment toward meeting the new demand for large-scale clinical studies. The National Institutes of Health ("NIH") are leaders in this effort to improve the quality of scientific evidence underlying decisions to employ particular technologies. ${ }^{35}$ Evaluations of important technologies have also been undertaken or subsidized by such specialized government agencies as the congressional Office of Technology Assessment ${ }^{36}$ and the National Center for Health Services Research and Health Care Technology Assessment. ${ }^{37}$ In addition to sponsoring definitive clinical studies, the federal government also presides over efforts to collect and harmonize professional opinion. Thus, the NIH convene so-called "consensus conferences" that purport to declare authoritatively what is and is not accepted practice. ${ }^{38}$ Some of the federal government's technology assessments have been undertaken specifically to guide its own spending on health services. The Medicare program, for example, must decide whether particular services are efficacious enough to be viewed as "reasonable and necessary" when prescribed for a Medicare beneficiary. ${ }^{39}$ Such governmental assessments provide data that may also be helpful to decisionmakers in the private sector. Whether government's incentives and imperatives lead to the optimal amount of investment in, or to pursuit of the right kinds of, technology assessment is a matter for conjecture. ${ }^{40}$

Although the public sector bears the primary responsibility for supplying public goods such as medical technology assessments, private entities may 62.

35. See Institute of Medicine, Assessinc Medical Technologies, supra note 20, at 40-41, 58-

36. See id. at 41-42, 424-36.

37. See id. at 43-44, 355-63.

38. See id. at 386-404; Perry, The NIH Consensus Development Program, 317 NEw EnG. J. MED. 485 (1987).

39. See generally National Advisory Council on Health Care Technology assessment, The Medicare Coverage Process (1988). The Medicare program must also determine which technological developments warrant adjustments (upward or downward) in allowances to hospitals under the so-called "prospective payment system"- - under which Medicare pays hospitals a fixed amount deemed sufficient to cover care for a typical patient with the particular patient's diagnosis. See Office of Technology Assessment, Medicare's Prospective Payment System: Strategies for Evaluating Cost, Quality, and Medical Technology 113.27 (1985).

40. Even in the British National Health Service (where benefits and costs are internalized to a greater degree than in U.S. financing), there are doubts whether the government assesses technology as carefully or systematically as it should. See generally B. Jennetr, supra note 17; H. AARON \& W. Schwartz, The Painful Prescription: Rationing Hospital Care (1984); A. Cochrane, supra note 17. 
also engage in activities that are useful in improving understanding and increasing knowledge. Because of the difficulties of marketing public goods, however, private technology assessment is more likely to be undertaken by large organizations that can themselves internalize enough of the benefit to justify the cost. There will also be a predictable tendency to concentrate, not on conducting costly clinical trials, but on such cheaper and less reliable activities as literature reviews and the sampling of expert opinion. The national Blue Cross and Blue Shield Association, for example, which comprises plans that in the aggregate underwrite health care for a significant percentage of the population, has had some incentive to undertake cooperative information gathering. ${ }^{41}$ Its efforts, however, have stopped short of commissioning independent clinical trials of particular technologies. Although all public and private payers for medical care have an interest in obtaining information bearing on technology, most of them tend to follow the herd, relying on the largest financers-especially the Blues and the Medicare program-to collect, distill, and act rationally in accordance with the best information available.

Much of the privately generated information concerning medical technology emanates from professionals and professional organizations. For example, the American College of Physicians, purporting to be concerned about both quality and cost, has initiated an ambitious program to propose practice protocols in internal medicine. ${ }^{42}$ Other professional bodies, like the $\mathrm{AAO}$ in the radial keratotomy cases, also appear to accept professional and scientific responsibility to assist physicians and others in making sensible use of new technologies. ${ }^{43}$ The participation of professional organizations in technology debates raises antitrust concerns prompted by the perception of a possible conflict of interests. It also, however, offers the public access to a valuable reservoir of knowledge and insight. As will appear below, the issue that antitrust courts must resolve is whether professional sponsorship of technology assessment perpetuates professional dominance, thus impeding rather than promoting the movement toward a competitive market in which choices are made, with good information, by consumers and independent agents acting on their behalf.

Two alternative conclusions bearing on the antitrust status of a professional organization engaged in technology assessment might flow from observation of the variety of potential sources of technology-related information. One view might be that professional organizations are not likely to add enough new information to the available supply that society should worry about losing their possibly biased input. On the other hand, the availability of other sources of information might be thought to obviate the danger that professional organizations can perpetrate serious abuses or

41. Two programs of the Blues are described in Institute of Medicine, Assessing Medical Technologies, supra note 20 , at $309-27$.

42. See id. at 275-85.

43. Id. at 54-55. 
continue to dominate decisionmaking. The legal analysis to come will lean toward the latter view as being more in keeping with antitrust policy.

\section{Monopoly Versus Pluralism}

To some observers, medical technology assessment has a third element in addition to the synthesis of existing information and the development of new knowledge-namely, the incorporation of findings into official guidelines or regulations that govern the implementation of the technology in question. ${ }^{44}$ This view points toward a single, definitive assessment of each technology to be undertaken under auspices that supposedly ensure objectivity and scientific validity. The model that comes to mind is the U.S. Food and Drug Administration ("FDA"), which controls the marketing of prescription drugs and medical devices.

The use of medical technology need not be governed by centralized decisions, however. Logically, choices about whether and how various technologies should be used could be left to the competitive market, which comprises a multiplicity of decisionmakers, each accountable in some way to consumers for the efficacy, quality, and cost of the care provided. In a competitive market, technology assessments would be viewed, not as steps in formulating governmental regulations or binding professional protocols, but as efforts to facilitate better decisions at all levels, public and private. It would be taken for granted under a decentralized, competitive regime that all decisionmakers would not necessarily interpret the available data in the same way, make the same tradeoffs, or heed the assessors' particular advice. A corollary would be that technology assessments should emanate from diverse sources and not be monopolized by a single authoritative agency, public or private.

In fact, the regulation that already governs some medical technologies stops well short of controlling their actual use in medical practice. Even though the FDA makes clinical evidence of safety and efficacy a prerequisite to the marketing of pharmaceutical products and medical devices, ${ }^{45}$ it lacks the power to control the use of technologies once they are approved; at the same time, the FDA seeks to improve the quality of information available to medical practitioners and their patients by regulating advertising and prescribing labeling for approved products. ${ }^{46}$ On the other hand, some regulatory

44. See Foote, supra note 20, at 60; Blumenthal, supra note 21.

45. The FDA's programs are summarized in Institute of Medicine, Assessing Medical Technologies, supra note 17, at 41-53.

46. On FDA regulation of advertising and labeling, see generally Fisherow, The Shape of Prescription Drug Advertising: Survey of Promotional Techniques and Regulatory Trends, 42 Food Druc Cosm. L.J. 213 (1987). In 1980 the FDA adopted regulations requiring that certain prescriptions be accompanied by package inserts developed specifically for patient use, 45 Fed. Reg. 60, 754 (1980), but these regulations were subsequently retreated from, 47 Fed. Reg. 39, 249 (1982). See Kendellen, The Food and Drug Administration Retreats from Patient Package Inserts for Prescription Drugs, 40 Food Drug Cosm. L.J. 172 (1985). 
mechanisms affecting technology-specifically, state certificate-of-need laws ${ }^{47}$ and federally sponsored Peer Review Organizations ${ }^{48}$-are expressly designed to curb overutilization of services. They, too, leave medical practitioners a great deal of clinical discretion, however. In general, the lack of enthusiasm for a "cookbook" regulatory approach to medical care reflects a sense that medicine is an art as well as a science and that patients vary not only with respect to their medical conditions but also with respect to their personal circumstances, needs, and preferences. Despite the general belief that medical practice should reflect the latest scientific understanding, there is little sentiment for trying to foster enlightened practice standards by regulatory compulsion rather than by education.

Although technology assessment by professional organizations can be viewed simply as a "procompetitive" input into a pluralistic process of decentralized decisionmaking under competitive incentives, the vision of the health care marketplace implicit in this conceptualization may not be realistic. The discussion here considers whether failings of the marketplace-mostly as a result of private decisionmakers' refusal to accept independent responsibility for choices concerning the uses of medical technology-might be deemed to warrant the use of antitrust law to take technology assessment out of the hands of organized professional interests. This discussion should help in the legal analysis to follow.

1. The Problem of Undue Reliance on Collective Judgments. The model of a competitive market driven by the independent choices of consumers and their agents, though seeming to legitimize professional organizations' pronouncements on technological issues, is strikingly at odds with the medical profession's traditional role in medical decisionmaking and with the profession's own ideology and perception of itself. Although the tenets of professional ideology are nowhere set down in official form, they can be deduced from the medical profession's actual performance during the period when it exercised de facto control over health care financing. Judging from that experience, professional dogma appears to include such beliefs as the following: that safety and efficacy are the only relevant considerations in evaluating medical care; that decisions on utilization of health resources should not turn on cost or the patient's ability or willingness to pay; that decisions on the financing of medical practice are exclusively a professional and scientific matter not amenable to consumer choice; and that health insurance should cover without question all care that is within professional

47. State certificate-of-need laws attempt to control utilization of some costly technologies by imposing gross limits on the supply thereof. See generally C. Havighurst, Deregulating the Health CARE Industry 53-74 (1982); Simpson, Full Circle: The Return of Certificate of Need Regulation of Health Facilities to State Control, 19 IND. L. Rev. 1025 (1986).

48. Although federally sponsored Peer Review Organizations have some occasions to police overutilization of services, the professional norms they employ leave practitioners free to choose within a fairly wide range. $C f$. Havighurst \& Blumstein, supra note 22, at 38-68. 
norms, excluding only that which is demonstrably harmful or wasteful.49 Given these decisionmaking criteria and ingrained perceptions of the relative roles of professional and other decisionmakers, a professional organization pronouncing its opinions on medical technologies is quite likely to believe that its word should be received not merely as advice but as gospel. If the effect of its pronouncements is to perpetuate a professional monopoly over crucial choices concerning medical care, there would be a problem that might concern an antitrust court.

A professional organization's claim of de facto authority to resolve technology issues for society as a whole would be inconsequential if the market's many independent decisionmakers were appropriately skeptical, treated authoritative pronouncements as subject to bias, routinely employed other sources of information in making their judgments, and took into account values, such as cost considerations, that professional groups tend to neglect. Unfortunately, it is not clear that those administering public or private health care programs are prepared to take much independent responsibility for hard choices concerning health care technology. Indeed, payers often rely heavily, if not exclusively, upon professional organizations in deciding what services to cover. In particular, some Blue Cross and Blue Shield plans, perhaps as a carryover from their long-standing alliances with provider interests, may approach technology assessment with essentially the same philosophy as professional groups. ${ }^{50}$ Under this philosophy, the object of a technology assessment would be the development of a universal, professionally validated payment policy rather than merely the provision of better information for use by individual plans and their customers in customdesigning coverage to suit particular needs and pocketbooks.

Although payers relying on professional consensus may simply be doing the best they can in a world with inadequate information, their refusal to exercise independent judgment perpetuates the old notion that the medical profession should determine payment policies and denies consumers the benefit of real competition. Of course, any collusive agreement by insurers and others to avoid competition over crucial variables-by delegating

49. For a typical statement by an official of the American Medical Association, see Newton, Henderson Man Batlles System for Cancer Treatment, Life, Durham Morning Herald, Mar. 26, 1989, at Al, col. 1, A 10, col. 1 (" As long as there is evidence that a drug is of value, it should be reimbursable." ) See generally Havighurst, supra note 24, at 700-08; Havighurst \& King, Private Credentialing of Health Care Personnel: An Antitrust Perspective (pts. I \& 2), 9 AM. J.L. \& MED. 131, 263, 288-92 (1983)(discussing "ideology in medical care"); Havighurst \& Blumstein, supra note 22, at 25$30,41-45$.

50. See Havighurst, supra note 29, at 248-54. Although compecitive pressures have forced many of the Blue plans to defect from their previous alliances and to come over to the consumer's side, others may still make common cause with providers, using their market power to support rather than to challenge provider cartels, which serve in turn to disadvantage the Blues' competitors. Id. In any event, the same large aggregate market share that makes the Blue plans a promising private source of technology assessments (despite the public-good character of such information) also implies a possible risk that better information is being generated, not to facilitate decentralized decisions in a competitive market, but to strengthen the dominant system and the perception that it is being operated responsibly in consumers' interest. 
responsibility to professional bodies or otherwise-would be an antitrust violation. $^{51}$ But universal acceptance of professional judgments on a technology question might reflect only "conscious parallelism" resulting from each payer's understandable fear of finding itself in a publicly exposed position of denying payment-on sensitive benefit/cost grounds-for physician-prescribed, arguably beneficial care that would be covered under competing plans. ${ }^{52} \mathrm{~A}$ market-oriented health policy would contemplate that competing payers will design and enforce rational, efficient coverage for various subsets of the consuming public. Unfortunately, the medical profession's dominant decisionmaking role ${ }^{53}$ coupled with the legal ${ }^{54}$ and public relations ${ }^{55}$ problems that "go-it-alone" cost-containment efforts are certain to encounter, may make it unrealistic to expect competition to yield pluralistic results anytime soon. ${ }^{56}$

Undue unanimity of attitudes toward medical technologies might also result from a propensity of public and private decisionmakers to take their cue unthinkingly from government. An instructive example involves the decision by the FDA in 1983 to authorize the sale of cyclosporin, the immunosuppressant drug that significantly increased the feasibility of liver, heart, and heart/lung transplantation. ${ }^{57}$ The FDA's action was viewed by many payers as a sign that transplantation of these organs was no longer "experimental" and should therefore be treated as a covered service despite its extraordinary cost and its debatable benefit/cost ratio in many cases. ${ }^{58}$ Though not universal, the widespread move to adopt this technology solely on the strength of the FDA's approval is striking because the FDA focuses only on the drug's safety and efficacy and does not even purport to weigh all

51. See, e.g., infra text accompanying notes 101-03. Cf. Havighurst, supra note 28, at 1148-50.

52. On the evidence necessary to establish the collusion requisite for finding a Sherman Act violation, see infra note 92.

53. The medical profession has never really conceded the legitimacy of decisions by laycontrolled entities on medical matters. See supra notes 25, 49. Partly as a consequence, employers, insurers, hospitals, and other potential agents of consumers have been slow to act without professional sanction.

54. See Havighurst, supra note 29 , at $240-42$, discussing insurance regulation as a constraint on various cost-containment measures that insurers might undertake. One legal risk that insurers face in limiting their coverage of any treatment supported by medical consensus is tort liability for denying payment in "bad faith." See C. Havighurst, Health Care Law and Policy 1204-12 (1988).

55. Some of the practical difficulties, stemming from public-good and free-rider problems, of getting insured employment groups to accept cost-containment measures that are actually in their economic interest are noted in Havighurst, Private Reform of Tort-Law Dogma: Market Opportunities and Legal Obstacles, Law \& Contemp. Probs., Spring 1986, at 143, 171 n.91.

56. For discussion of comparable tendencies of payers and others to follow professional guidance on other, similar matters, see Havighurst, supra note 28, at 1148-51 (insurers' tendency to be guided by professionally sponsored bodies engaged in evaluating fees, utilization, and quality of care); Havighurst \& King, supra note 49, at 155-57, 164, 166, 177-78, 193-94 (tendency of hospitals and other institutions to respect professionally sponsored credentialing of health care personnel).

57. Food \& Drug Administration, U.S. Dep't of Health and Human Services, HHS News, PuB. No. 83-19 (Sept. 2, 1983).

58. See Havighurst \& King, Liver Transplantation in Massachusetts: Public Policymaking as Morality Play, 19 IND. L. REv. 955, 965-66 (1986). Cf. Newton, supra note 49, at A10, col. 1 (Blue Cross plan official quoted with respect to Interleukin-2, a cancer drug: "Most carriers have to look to the outside for direction on where coverage will enter. We seek the FDA approval."). 
the factors relevant to a rational decision to incur the costs of transplantation. This experience is further evidence of the desire of many public and private decisionmakers to avoid hard choices by relying upon any seemingly authoritative decisionmaker who is available, even one who ignores relevant considerations.

Although it is hard to judge both the current situation and the potential for evolution toward de facto as well as de jure decentralization of decisionmaking responsibility, it is possible that the marketplace is not currently meeting the challenge of screening medical technologies on benefit/cost grounds. This is not to concede, however, either that some other mechanism is capable of performing the task better or that arguable shortcomings of competition as an allocator of health care resources have any bearing on antitrust analysis.

2. The Case for Pluralism. Private resistance to making hard choices concerning medical technologies on a decentralized basis may easily be interpreted as evidence of a societal desire for centralized decisions and as the Achilles heel of a policy of seeking allocative efficiency through market mechanisms. The desire for one big Technology Assessment leading to a definitive public decision on the specific uses of each new medical product or procedure is also reflected in common casual statements-often by those who should in theory be assuming responsibility themselves-to the effect that society as a whole must make difficult collective choices concerning medical technology. ${ }^{59}$ Instead of reflecting a desire for better information to guide pluralistic decisions, the movement for better technology assessment may reflect simply a desire for an authoritative final arbiter that is more reliable and accountable than medicine's own institutions have proven to be. ${ }^{60}$

Although there is a legitimate policy question whether medical technology assessment should be incorporated into a unitary command-and-control system or should be viewed merely as an aid to decisionmaking in a pluralistic marketplace, a court should consider itself bound to adopt the latter view by the premises of the antitrust laws. The health care industry is, after all, nominally competitive, lacking a statutory warrant for operating on a different basis. Moreover, because market forces are not totally inoperative in health care and are capable of taking firmer hold as cost and other pressures intensify, it might be bad policy for the future development of the industryas well as bad law-for an antitrust court to view pronouncements by professional groups on technology questions as suspicious acts. A joint venture yielding a new product-especially consumer information that, as a

59. See, e.g., Havighurst \& King, supra note 49; Newton, supra note 49 at A10, col. 1 .

60. It is not in fact clear that society has reexamined its earlier assumptions about the nature of technology issues or fully accepted the appropriateness of decentralized decisionmaking on medical matters. For the argument that economizing in the use of costly life-saving technologies will be somewhat easier if decisions are increasingly made in the private sector on a decentralized basis, see Havighurst, Blumstein \& Bovbjerg, Stralegies in Underwriting the Costs of Calastrophic Disease, LAw \& Contemp. Probs., Autumn 1976, at 122. 
public good, might otherwise be underproduced-would seem highly procompetitive on its face. To be sure, technology assessment-like other concerted informational activities, such as cooperative advertising and competitor-sponsored accrediting, credentialing, and certification programs ${ }^{61}$-may harm some competitors. Nevertheless, consumers would probably suffer greater injury if antitrust courts, in an attempt to promote fairness and objectivity, discouraged knowledgeable groups from participating in technology debates.

The policy arguments for allowing wide participation in medical technology assessment need not rest solely upon faith in competition as an efficient allocator of health care resources. There are also good scientific reasons for preferring a multiplicity of participants in any evaluation effort. First, few studies of medical technologies yield definitive and final results. Most raise questions to be answered by the next study, and parallel studies do not necessarily duplicate each other but may instead yield deeper insights or serendipitous findings. Second, because few investigators are immune from mistakes or bias in designing an experiment or interpreting findings, scientists often distrust experimental results until they are replicated in other studies. Diversity in-that is, competition among-the sources of information concerning medical technologies would seem socially advantageous without regard to whether the ultimate decisions are to be monopolized by government or left to the pluralistic marketplace. ${ }^{62}$

III

\section{Antitrust Liability for Expressing Collective Opinions?}

As long as a professional group confines itself to issuing opinions that bind no one and publishing information for others to use, it might seem that its actions could not possibly be characterized as being in restraint of trade. After all, "trade"-that is, competition-is a process requiring nothing more than a multiplicity of independent decisionmaking units whose interactions and choices are conclusively presumed under the statutory policy to yield socially desirable results. The publication of opinions and information concerning the goods and services available in the marketplace does not disrupt that process, nor does it directly alter the market's configuration or diminish its competitiveness. Even if the behavior of market participants is greatly influenced by what they hear and even if some competitors are consequently hurt, the process is still intact. Indeed, it could be said to have operated, with the information available, precisely as the law contemplates it should.

61. See infra notes 68,69 and accompanying text.

62. See Institute of Medicine, Assessing Medical Technologies, supra note 20, at 13 ("The committee endorses this pluralism, believing that it contributes to the richness and variety of assessment activities and serves as a system of checks and balances."). 
Although the Schachar case was ultimately dismissed under the foregoing theory, ${ }^{63}$ professional bodies that express opinions on technical matters should probably still be prepared to face some antitrust scrutiny. Such organizations are clearly "combinations" of competitors. And even if the concerted action in which they are engaged does not directly restrain trade, it has possible implications for the market's good performance. Not all courts are as rigorous as Judge Easterbrook in identifying whether, or precisely how, the competitive process has been disrupted in a particular case. Instead, they often seem to use fairness and notions of equal opportunity as their criteria for permissible concerted action and to rely upon subjective estimates of consumer welfare as their measure of whether the market is working as it should. ${ }^{64}$

The radial keratotomy cases provide a good illustration of the issues here. Even though the defendants' actions clearly hampered the plaintiffs in their efforts to offer or obtain the new procedure, those actions might be viewed only as serving the procompetitive purpose of advising interested persons on an important technical issue, enabling them to make better-informed purchasing decisions. Not only would Judge Easterbrook have no trouble subscribing to this view, but even activist judges willing to regulate all concerted action by standards of their own making might listen to policy arguments for limiting their scrutiny of conduct that amounts to nothing more than the expression of a collective opinion. As noted at the conclusion of this section, plaintiffs in such cases will usually allege that the defendants did more than just express an opinion. Nevertheless, clarification of the legal status of mere speech should assist courts in handling cases of this kind.

\section{A. Conflict of Interests as a Basis for Close Judicial Scrutiny}

An antitrust court's reluctance to dismiss cases of this kind might rest upon the perception that criticism of a new technology may not be inspired solely by professional or scientific concerns or by a magnanimous desire to produce a valuable public good. Objectivity may be distorted by an interest in preventing practitioners of the new technology from competing effectively with the dominant providers or by other interests. Some of the defendants in the radial keratotomy cases, for example, although seemingly motivated by true scientific doubts and a sense of their professional gatekeeping responsibilities, may also have harbored anticompetitive objectives. Alternatively, the defendants may simply have resented the large fees and the presumptuousness of the entrepreneurial surgeons who pioneered the field

63. See supra text accompanying notes 10-15.

64. Boycott law provides examples. Instead of recognizing that competition is ipso facto eliminated by any agreement in which competitors surrender their independent discretion and adopt a common policy toward particular customers or suppliers, courts tend to focus on the unfairness of the boycott and on the specific harm that consumers might suffer. See the fuller discussion, citing cases, in Havighurst, Doctors and Hospitals: An Antitrust Perspective on Traditional Relationships, 1984 DUKE L.J. 1071, at 1104-09. 
without waiting for academic medicine to approve. ${ }^{65}$ In any event, the defendants were able to capture some of the radial keratotomy business for themselves by obtaining federal funding for a clinical trial, under which their own institutions became the most attractive providers of the procedure and other institutions, without third-party payment, were placed at a competitive disadvantage. ${ }^{66}$ The fact that radial keratotomy was eventually determined to be a moderately good technology ${ }^{67}$ may add credence to conflict-of-interests allegations while also strengthening both the impression of unfairness and the perception that consumer welfare was not well served.

Antitrust courts asked to regulate the collective publication of information and opinion concerning medical technology may be prompted by the apparent conflict of interests of the publishing organization to inqui : deeply into the honesty of the opinions expressed and the accuracy of the information conveyed. Although such skepticism is not misplaced, it does not follow that close judicial scrutiny is the right response. The health care industry is not unusual in the extent to which it relies upon self-interested producers to supply vital information. Given the underproduction of disinterested information concerning products and services of all kinds, producers are frequently the consumer's main source of data helpful in making purchases. ${ }^{68}$ Commercial advertising, both by individual sellers and by trade associations, is the most obvious example of information that is useful to consumers despite its skepticism-inducing source. Another example is the information supplied to consumers and others by competitor-sponsored accrediting, credentialing, certification, and standard-setting programs. Although such programs are sponsored by competitors and can severely disadvantage other competitors, antitrust courts have usually viewed them favorably-precisely because of the informational function they perform. ${ }^{69}$ Profession-sponsored technology assessments, which may also involve

65. See 870 F.2d at 399 :

Plaintiffs say that the Academy is in the grip of professors and practitioners who favor conservative treatment, forever calling for more research (the better to justify the academics' requests for grants); plaintiffs portray themselves as the progressives, disdaining the Academy's fuddy-duddies in order to put the latest knowledge to work.

66. But see id. at 398-99 (noting that some plaintiffs still performed the procedure frequently and that, in any event, had not alleged that they were actively prevented from doing so).

67. An opinion to this effect was issued as a result of the settlement in Vest v. Waring, $565 \mathrm{~F}$. Supp. 674 (N.D. Ga. 1983). See supra note 7. For a consumer group's view of the procedure, see Goodbye Glasses?, Consumer Reports, Jan. 1988, at 52. Such assessments are unusual in the popular press.

68. See generally Havighurst \& King, supra note 49, at 152-55. The obvious exception is the nonprofit Consumers Union with its authoritative Consumer Reports. See supra note 67.

69. See, e.g., Allied Tube \& Conduit Corp. v. Indian Head, Inc., 108 S. Ct. 1931, 1937 (1988) ("private standards can have significant procompetitive advantages"); Clamp-All Corp. v. Cast Iron Soil Pipe Inst., 851 F.2d 478, 486-89 (1st Cir. 1988) (upholding defendants' efforts to influence product certifiers); Consolidated Metal Prods. v. American Petroleum Inst., 846 F.2d 284, 296 (5th Cir. 1988) ("Even if user reliance gives API significant influence over the market, that influence may enhance, not reduce, competition and consumer welfare."). See also Havighurst \& King, supra note 49 , at $169-84$. 
authoritative but debatable assertions concerning competitors' services, might be regarded as similarly procompetitive. ${ }^{70}$

Competitors' collective claims of superiority for their products or services are also procompetitive in the less subtle sense that they are self-interested efforts to compete on the merits. Although those who would justify professional technology assessment as a service to the public are not inclined to see the point, self-interest is no sin-nor even a suspicious circumstancein a competitive world where producers' pursuit of their own welfare is presumed to advance the public interest. Thus, the suspicion that a professional group may be less than wholeheartedly committed to serving the public ought not to affect analysis in an antitrust case. Nor should the desire of some professional groups to be judged as servants of the public interest cause an antitrust court to view them other than as private groups entitled to pursue their own interests in any way that is not inconsistent with the maintenance of competition.

Further guidance on the proper scope of antitrust scrutiny of professionsponsored technology assessments may be gained by considering the limited, but still substantial, protection accorded by the first amendment to so-called "commercial speech"-that is, producers' representations about their own or their competitors' products. ${ }^{71}$ Public regulation of such speech is permitted not only because of the commercial context but also because of the speakers' powerful incentive to mislead. On the other hand, the Supreme Court has said that commercial speech deserves some constitutional protection because the information provided is valuable both to consumers individually and to the market itself in allocating resources. ${ }^{72}$ This acknowledgment of the instrumental, market-strengthening character of free-speech rights suggests a high degree of congruence between the constitutional policy of limiting governmental intrusion into the marketplace of ideas and antitrust law's pragmatic concern that the economic marketplace not be prevented from working as intended. The analogy observed may suggest that antitrust law should always lean, as does the Supreme Court in first amendment matters, toward solutions that rely primarily on fostering additional sources of

70. The Schachar court relied directly on the cases cited supra note 69.870 F.2d at 399 .

71. See, e.g., In re R.M.J., 455 U.S. 191, 203 (1982) ("the states may not place an absolute prohibition on [advertising] certain types of potentially misleading [commercial] information ... if the information also may be presented in a way that is not deceptive"); Virginia State Bd. of Pharmacy v. Virginia Citizens Consumer Council, 425 U.S. 748 (1976) (invalidating state restrictions on advertising by pharmacists of prices of prescription drugs). On the definition of commercial speech, see infra note 74 .

72. See Virginia State Bd. of Pharmacy, 425 U.S. at 765 (citations omitted), where the Court stated,

So long as we preserve a predominantly free enterprise economy, the allocation of our resources in large measure will be made through numerous private economic decisions. It is a matter of public interest that those decisions, in the aggregate, be intelligent and well informed. To this end, the free flow of commercial information is indispensable.

Other first amendment cases placing primary reliance, not on the abstract rights of speakers, but on the hearers' rights include Bigelow v. Virginia, 421 U.S. 809 (1975); Lamont v. Postmaster General, 381 U.S. 301 (1965). See also infra note 73. 
information-that is, more competition in the marketplace of ideas-rather than on suppressing speech or regulating its accuracy and content. ${ }^{73}$

The commercial-speech doctrine takes explicit notice of the conflict of interests of the parties seeking to influence consumer choices. ${ }^{74}$ Indeed, the Supreme Court has given the strength of the speaker's economic interest as one of its reasons for according commercial advertising less protection than political speech, observing that this conflict of interests lessens the danger that desirable speech will be chilled by regulation. ${ }^{75}$ This point seems to cut in the opposite direction for present purposes, however, because antitrust regulation, with its treble-damage sanction and uncertain standards, is clearly capable of stifling even the most self-interested speech; the chilling effect would be even greater to the extent that the speakers were motivated by professionalism and a commitment to scientific learning. Thus, whatever other regulation might be appropriate to discourage false and deceptive technology assessment, ${ }^{76}$ limited scrutiny of commercial speech by antitrust courts may be the furthest a court can go without violating either antitrust or first amendment policy. Indeed, with a proper appreciation of antitrust's preference for pluralism, it should not be necessary to invoke the Bill of Rights at all. Antitrust doctrine should equally reflect the conclusion that an apparent conflict of interests alone is not enough to trigger judicial scrutiny that goes beyond establishing the facial legitimacy of a collective effort to inform.

73. The Schachar court's discussion quoted infra in text accompanying note 81 is particularly illuminating. Cf. Virginia State Bd. of Pharmacy, 425 U.S. at 769 , where the Court rejected the consumer-protection arguments for regulation suppressing price advertising because "on close inspection it is seen that the State's protectiveness of its citizens rests in large measure on the advantages of their being kept in ignorance," a policy strategy that the Court deemed the first amendment to preclude. See also Red Lion Broadcasting Co. v. FCC, 395 U.S. 367 (1969) (upholding against a first amendment challenge the FCC's "fairness doctrine," a regulation curbing broadcasters' editorial freedom but serving the greater constitutional interest in seeing that viewers have access to a wider range of information and opinion.) But see Miami Herald Publishing Co. v. Tornillo, 418 U.S. 241 (1974) (reaching different result for newspapers).

74. Indeed, the economic interest of the speaker in the message being conveyed would seem to be a defining characteristic of commercial speech. See Bolger v. Youngs Drug Prods. Corp., 463 U.S. 60, 66-67 (1983). Another defining characteristic is reliance on a commercial market rather than a political process as the forum from which "truth" is expected to emerge. Regulation of false and deceptive advertising is permitted, of course, in recognition of the strong motive of the advertiser to mislead and the state's police power to prevent commercial fraud. If the assumption of irremediable ignorance and gullibility on the part of consumers was valid (as it often is), public control would be a plausible response to a plausible ("clear and present") danger. In the case of technology assessments, however, the decisionmakers to whom the information is primarily addressed are not unsophisticated and would seem to have both the incentive and the capacity to collect relevant information and to make consumer-oriented judgments on the basis thereof. The argument for regulating this kind of (commercial) speech thus compares poorly with the arguments for regulating deceptive advertising. Indeed, technology assessments by professional organizations might well be deemed to fall outside the Supreme Court's narrow definition of "commercial speech," see id., and thus to qualify for more protection against regulation than advertising receives.

75. Virginia State Bd. of Pharmacy, 425 U.S. at $772 \mathrm{n} .24$ ("Since advertising is the sine qua non of commercial profits, there is little likelihood of its being chilled by proper regulation and forgone entirely.").

76. For example, section 2 of the FTC Act, 15 U.S.C. $\S 45$ (1975), allows the Commission to police "unfair or deceptive acts or practices." 


\section{B. Should De Facto Influence Trigger Close Scrutiny?}

The district judge in Schachar rejected the defendants' first amendment arguments by stressing the AAO's prestige and apparent authoritativeness, which were said to give its statements "significantly more weight and thus ... a more coercive effect than ... the views of individuals." 77 The court also saw great significance-enough to deny the defendants summary judgment-in the possibility that some third party payers, in refusing to pay for radial keratotomy, "may have relied in whole or in part upon defendants' statements."78 Although the court thus appeared to hold that a prestigious professional body must face antitrust liability whenever its debatable views on some controversial issue are found persuasive by others, it is possible that it meant no more than that such a body must be prepared to have its informational activities scrutinized for anticompetitive abuse. Such a holding would not purport to settle the question of the appropriate scope of judicial review. Nevertheless, the court's denial of summary judgment on the basis of the AAO's "coercive . . . influence"79 ensured that litigation would be costly even if the court would ultimately defer to professionalism or hold the plaintiffs to a high standard of proof. The district court was apparently not concerned by the possibility that vigorous debate and the flow of information and opinion would be chilled. It was certainly unprepared to accept the simple argument, later adopted by the court of appeals, that the competitive process, supplied with relevant information, had rendered a verdict that an antitrust court should regard as incontestable.

The Schachar district court and some other observers would presumably rationalize close judicial scrutiny of the informational activities of professional organizations by observing that the market for medical services does not work as the textbook model contemplates and, specifically, that some organizations speak with so much authority that they cannot be regarded merely as participants in an open debate. To be sure, as noted earlier, physician organizations have long been recognized as quasi-public authorities whose views are expected not merely to influence but to govern the actions not only of their own members but of other independent actors as well. The issue is thus nicely posed: Assuming that the world does still rely unduly upon professional pronouncements concerning medical technologies, is that reliance an excuse for antitrust courts to police closely the actions of influential professional bodies by providing vigilant judicial review of their pronouncements and awarding treble damages whenever they are found to abuse their de facto authority as technical advisors to professionals and the general public?80 The court of appeals in Schachar answered this question as follows:

77. 1988-1 Trade Cas. (CCH) I 67,986, at 58,052.

78. Id. at 58,052 n.4. But see supra note 66 .

79. See supra note 8 and accompanying text.

80. Strong support for a negative response is provided by Consolidated Metal Prods. v. American Petroleum Inst., 846 F.2d 284, 296 (5th Cir. 1988) (citations omitted): 
An organization's towering reputation does not reduce its freedom to speak out. Speech informed, hence affected, demand for radial keratotomy, but the plaintiffs had no entitlement to consumers' favor. The Academy's declaration affected only the demand side of the market, and then only by appealing to consumers' (and third-party payors') better judgment. If such statements should be false or misleading or incomplete or just plain mistaken, the remedy is not antitrust litigation but more speech-the marketplace of ideas. ${ }^{81}$

To subject a professional body to close judicial review solely on the basis of the influence it wields might be seen as penalizing its success in establishing its credibility and earning the confidence of independent decisionmakers. Putting aside, however, the arguable perversity of punishing such commercial success, there are other grounds for not regulating this kind of commercial speech. Antitrust courts are poorly equipped to evaluate the quality and honesty of opinions and information generated by professional organizations. By hypothesis, the issues are highly technical and controversial. Litigation closely examining the merits of these issues, the circumstances and effects of various pronouncements, the motives of the parties, the honesty of the opinions expressed, and the accuracy and completeness of the facts reported would always be protracted and costly. Yet it would usually be inconclusive on the central questions. ${ }^{82}$ Even if judges and juries were ultimately deferential to professionals in their final rulings,

\footnotetext{
Although there is some danger that API could use its influence to reduce competition, this danger is small so long as users rely voluntarily upon the API monogram. If users choose freely to rely on API approval, API has influence principally because it has done a good job evaluating products. If API fails to evaluate products accurately, consumers free to sample nonmonogrammed goods will gradually discover the monogram's diminished usefulness and cease relying upon it. Thus, the greatest threat to competition is in the short run, before a significant number of buyers shop around. Even this threat is mitigated to the extent that producers of unmonogrammed equipment have alternative means of reassuring consumers of the quality of their products. They may, for example, offer warranties, commission product tests by someone other than API, provide free (or low-cost) samples of their product, and advertise.
}

The court of appeals upheld summary judgment for the defendants, essentially taking a "quick look" to satisfy itself on the procompetitiveness of the product certification system. In American Soc'y of Mech. Eng'rs v. Hydrolevel Corp., 456 U.S. 556, reh'g denied, 458 U.S. 1116 (1982), the Court held a standard-setting body liable for abuses of its processes by agents acting in its name but actually on behalf of a particular producer seeking to exclude a compecitor's product. This holding is quite consistent with a policy of giving only limited scrutiny-a "quick look" under the rule of reason-to competitors' collective efforts to persuade and inform potential users of their products.

For an interesting nonantitrust opinion suggesting that the scope of judicial review of actions of an educational accrediting body should be calibrated according to the influence exercised, see Marjorie Webster Jr. College, Inc. v. Middle States Ass'n of Colleges and Secondary Schools, Inc., 432 F.2d 650 (D.C. Cir. 1970), cert. denied, 400 U.S. 965 (1970). For a critique of such a sliding-scale approach, see Havighurst \& King, supra note 49, at 164-66, $191-94$.

81. 870 F.2d at 399-400. The court also made clear that it was not the limited impact of the "experimental" label but the lack of any direct restraint of trade that undermined the plaintiff's case.

82. It is legitimate to develop antitrust rules to avoid inquiries that, while theoretically indicated, are likely to serve no useful purpose. Thus, courts have felt free to condemn certain practices under per se rules despite the possibility that deeper inquiry would discover redeeming procompetitive virtues. See, e.g., Arizona v. Maricopa County Med. Soc'y, 457 U.S. 332, 344 (1982); Northern Pac. Ry. v. United States, 356 U.S. 1, 5 (1958) (noting the appropriateness of conclusive presumptionsper se rules-that avoid "the necessity for an incredibly complicated and prolonged economic investigation ... - an inquiry so often wholly fruitless when undertaken"). There is less acceptance of the idea that similarly conclusive presumptions of legality might also sometimes be justified on the same basis. However, the argument for doing so, in order to avoid stifling conduct that is nearly 
the high cost of trying such cases might result in many costly settlements even when the defendants had great confidence in their ability to prevail. The potential for such costly and unpredictable lawsuits would ultimately deter physician groups from sponsoring technology assessment, leaving the task almost entirely to the public sector, which might not provide complete or timely guidance for decisionmakers and, depending upon how its assessments were done, might stifle diversity even more than professional bodies.

The alternative risk is that close judicial oversight would contribute to fulfilling the very prophecy and perpetuating the very market dysfunction that together provide the courts' rationale for intervening. Judicial review might simply confirm the defendant organization's status as a quasi-public body, thereby enhancing the credibility and influence of its pronouncements. Thus, if a professional body were willing to incur the cost of defending and even possibly losing an occasional lawsuit, it might achieve the very stature and authority it most covets. ${ }^{83}$ It might then be able to control developments more effectively than it could if courts took the opposite tack of treating professional bodies only as possibly biased participants in an open marketplace of ideas in which credibility is not ensured by judicial verification but must be earned by good performance. In the long run, professional authority is more likely to find its proper level under the skeptical eyes of market participants than under judicial supervision.

Faith that independent decisionmakers will be appropriately skeptical toward professional organizations may seem misplaced given their pusillanimity to date. The reasons why various decisionmakers have been reluctant to depart from professional consensus on matters relating to medical technology are difficult to identify. Some constraints are legal. ${ }^{84}$ Other explanations include the difficulty of capturing cost savings and avoiding free riders, fear of professional retaliation or criticism, the difficulty of educating consumers to their true economic interests, and the complex

always procompetitive and efficiency-enhancing, is powerful. See Barry Wright Corp. v. ITT Grinnell Corp., 724 F.2d 227, 234 (1st Cir. 1983) (citations omitted):

[U]nlike economics, law is an administrative system the effects of which depend upon the content of rules and precedents only as they are applied by judges and juries in courts and by lawyers advising their clients. Rules that seek to embody every economic complexity and qualification may well, through the vagaries of administration, prove counter-productive, undercutting the very economic ends they seek to serve. Thus, despite the theoretical possibility of finding instances in which horizontal price fixing, or vertical price fixing, are economically justified, the courts have held them unlawful per se, concluding that the administrative virtues of simplicity outweigh the occasional "economic" loss. Conversely, we must be concerned lest a rule or precedent that authorizes a search for a particular type of undesirable pricing behavior end up by discouraging legitimate price competition.

By analogy, antitrust scrutiny of informational practices should not be allowed to stifle the output of information and opinion.

83. Although only a few of the many actions that a professional body might take would expose it to antitrust suits, the prestige conferred upon the organization by courts reviewing those few activities-in the same manner that they review actions of public administrative agencies-would carry over to all its actions. For a comparable argument for limiting scrutiny of competitorsponsored accrediting and credentialing actions, see Havighurst \& King, supra note 49, at 193-94.

84. See supra note 54 . 
politics of employee health benefits. ${ }^{85}$ Although some of these constraints are being overcome as the private sector tries to resist rising health care costs, it may be a long time before decisions that are in the interest of consumers but contrary to medical consensus become routine. Even so, the needed demystification of the medical profession is not likely to result from closer oversight of professional organizations by antitrust courts. On the contrary, the best hope for competition would still appear to lie in opening up the marketplace of ideas, encouraging all interested persons to participate, and relying upon robust debate and criticism, an awakening private sector, and public sponsorship of technology assessment to bring us nearer to elusive scientific truths and informed consumer choices concerning medical technology. If the assumption that consumers will ultimately look out for their own interests proves wrong, legislatures can act either to dispense with independent decisionmaking or to improve the climate for it.

\section{Deciding These Cases}

The foregoing analysis suggests that antitrust courts should subject professional organizations to no more than limited scrutiny when they publish influential information and opinion concerning controversial medical technologies. Judge Easterbrook's opinion in Schachar can be read as going even further, precluding antitrust scrutiny altogether unless the defendants took additional steps to harm competition.86 Informational activities by competitor groups might sometimes be influential enough, however, to warrant scrutiny under a rationale similar to that underlying the so-called "essential facilities doctrine" of antitrust law, which applies when one group of competitors, with the potential for exercising market power, controls a resource to which other competitors must have access if they are to survive at all. ${ }^{87}$ Nevertheless, application of the rule of reason to detect adverse effects

85. See generally Havighurst, supra note 29, at 231-54 (exploration of causes of health insurers' reluctance to take independent action on health care costs).

86. The court found it decisive that the Academy had not "prevented [any plaintiff] from doing what he wished or imposed sanctions on those who facilitated the work" - e.g., by referring patients, paying for the procedure, or providing facilities. $870 \mathrm{~F} .2 \mathrm{~d}$ at 399 . But see infra note 87 .

87. See, e.g., Associated Press v. United States, 326 U.S. 1, 13 (1945) (dominant news-pooling association of newspapers); United States v. Terminal R.R. Ass'n, 224 U.S. 383, 397 (1912) (joint railroad control of sole river crossing); United States v. Realty Multi-List, Inc., 629 F.2d 1351,1355 (5th Cir. 1980) (multiple listing service); Gamco, Inc. v. Providence Fruit \& Produce Bldg., Inc., 194 F.2d 484, 486-89 (I st Cir. 1952) (joint control of favorably located warehouse), cert. denied, 344 U.S. 817 (1952). On competitor collaboration in research and development joint ventures, see Department of Justice, Antitrust Guide Concerning Research Joint Ventures 21 -24 (Nov. 1980) (indicating that a dominant venture, if lawful at all, would not be allowed to exclude competitors arbitrarily). For a fuller discussion of the essential-facilities doctrine in connection with physician control of the award of hospital staff privileges, see Havighurst, supra note 64, at 1111-25. For another application of these principles to competitor-sponsored informational activities, see Havighurst \& King, supra note 49 , at 176-84.

Despite the holding reported supra note 86 , the Schachar court left room for this theory of antitrust liability by observing that an antitrust cause of action might lie if "one group of suppliers diminishes another's ability to peddle its wares (technically, reduces rivals' elasticity of supply)," $870 \mathrm{~F} .2 \mathrm{~d}$ at 399 , and by noting the trial court's "puzzling refusal to define a product market even though the first question in any rule of reason case is market power," id. at 398 . Market power is a necessary element 
on competition under this theory need not involve more than a "quick look" 88 by which the court can satisfy itself that the defendants lacked market power or that the information or opinion tendered had a rational basis. No more extensive scrutiny should be undertaken, because there is no less restrictive way to accomplish the procompetitive informational purpose $\mathrm{e}^{89}$ and, as argued above, the activity is more procompetitive than anticompetitive. Not being facially inconsistent with the maintenance of competition as a process, collective speech should not have to be justified affirmatively on the ground either that it is disinterested or that its informational content actually advances consumer welfare. ${ }^{90}$

Even if courts generally agreed to limit their scrutiny of collective expressions of opinion and assertions of fact, these cases might still be complicated by plaintiffs' predictable allegations that the defendants did not confine themselves to publishing opinions and information but also engaged in more conventional restraints of trade. Both horizontal and vertical restraints might be alleged. The discussion here suggests how such allegations can be handled without deterring useful collaboration.

\section{Direct Horizontal Restraints? Horizontal agreements that eliminate} competition between the parties themselves are the Sherman Act's primary concern and are conceptually distinct from agreements by competitors merely to formulate and advocate a particular view on some technical matter.91 Nevertheless, even though an association's members may not explicitly agree

in an essential facilities case because antitrust law should be invoked only if the joint venturers would be able to influence price, output, or competitive behavior if the rivals victimized by their practices left the market.

88. See 7 P. Areeda, Antitrust Law 11511 (1986) (discussing how the dichotomy between per se offenses and other cases is breaking down as courts learn to apply the rule of reason expeditiously - sometimes "in the twinkling of an eye"-thus obviating extensive inquiry where the court can quickly ascertain whether the elements of an offense are present).

89. On the less-restrictive-alternative requirement, see infra note 95.

90. See supra note 80 .

Even though society might be legitimately concerned about false or deceptive assessments of medical technology, that concern alone does not bring the collective publication of information and opinion within range of the Sherman Act, which is appropriately concerned with "unfair competition" only when it threatens to create undue market power. For example, the offense of attempted monopolization under section 2 of the Sherman Act, 15 U.S.C. $\S 2$ (Supp. 1988), is usually thought to require proof of a "dangerous probability" that the defendant will succeed in creating a true monopoly. See, e.g., Handler \& Steuer, Attempts to Monopolize and No-Fault Monopolization, 129 U. PA. L. Rev. 125, 128-29 (1980).

Although other legal weapons might be employed to curb informational abuses that do not qualify as antitrust violations, an antitrust court should be unwilling to determine, at the behest of competitors, the truthfulness and the completeness of the statements made. A policy requiring these issues to be litigated in such a court would restrain more trade than it would protect. Despite this logic, some courts will still no doubt sense a mandate to ensure fairness in the competitive struggle and will use the Sherman Act as their warrant for policing falsity and deceptiveness. Even so, the standard for identifying abuses should recognize that the competitive process is not impaired, and indeed is rendered more dynamic, by spirited debate. Thus, it should leave ample room for judgment in the interpretation of evidence and for differences of opinion on important matters, looking only far enough to discern whether there is a rational basis for the pronouncements made. 13.

91. The Schachar court was especially clear on this point. See supra text accompanying notes 11- 
to abide by the group's announced view, a plaintiff might allege a tacit conspiracy to eschew using the questioned technology or to boycott those who do use it. A high degree of uniformity in the members' response to the new technology-conscious parallelism-would make the conspiracy charge a challenging one. Unfortunately, the distinction between a lawful agreement merely to express a collective opinion and an unlawful agreement to tailor competitive conduct in accordance with that opinion is much clearer in theory than the factual distinction between such agreements is likely to be in a particular case.

Antitrust courts generally require substantially more than conscious parallelism to establish a horizontal conspiracy. ${ }^{92}$ Not only must so-called "plus factors" also be established, ${ }^{93}$ but courts have been hesitant to infer a conspiracy even when such circumstantial evidence is presented. ${ }^{94}$ Indeed, it is ironic that antitrust courts may be quicker to scrutinize collaborative statements for signs of what they regard as an anticompetitive motive (that is, a desire to win the competitive race) than they are to view those same pronouncements as signals for truly anticompetitive collusion. In any event, any threat by the professional group to enforce its view against its own members-perhaps in the form of an ethical proscription or an implicit threat of expulsion from membership-would open the group to antitrust attack. Likewise, any hint of a concerted refusal by the members to deal with, or to refer patients to, practitioners of the questioned technology would also be challengeable on the theory that the competitors had surrendered their responsibility for making independent judgments under competitive pressures and constraints.

Even though a horizontal conspiracy is difficult to establish by proof of conscious parallelism and plus factors, the potential for costly litigation exists. Thus, a professional organization would be well advised to lay what groundwork it can for getting potential charges of conspiracy dismissed quickly. Thus, it should disavow in its opinions any intention to dictate its members' conduct and should demonstrate real tolerance for diverse behavior and opinions within its membership with respect to the technology in question. Because professional organizations can rather readily avoid conduct that is truly conducive to collusion while still performing their informative functions, the threat of antitrust litigation based on horizontal collusion should not deter truly procompetitive activities. One need have no special sympathy for a professional body that gets enmeshed in protracted,

92. See Theatre Enters., Inc. v. Paramount Film Distrib. Corp., 346 U.S. 537, 541 (1954). Parallel conduct attributable to oligopolistic interdependence may be unlawful, however, even if an actual agreement to refrain from competitive behavior cannot be inferred. Interstate Circuit, Inc. v. United States, 306 U.S. 208, 222-23 (1939) (dictum). An inference of actual or tacit collusion is generally recognized as permissible where the parallel conduct would be contrary to the self-interest of each individual competitor unless all competitors acted in the same manner. See Ambook Enters. v. Time, Inc., 612 F.2d 604, 614 (2d Cir. 1979), cert. dismissed, 448 U.S. 914 (1980); Bogosian v. Gulf Oil Corp., 561 F.2d 434, 445-47 (3d Cir. 1977), cert. denied, 434 U.S. 1086 (1978).

93. See generally Hay, Oligopoly, Shared Monopoly, and Antitrust Law, 67 Cornell L. Rev. 439 (1982).

94. See P. Areeda \& L. Kaplow, Antitrust Analysis 288-315 (1988). 
costly litigation because it failed to take steps to dispel any belief among its members that they were expected to share, and conform their conduct to, the majority's views. Because of the danger that concerted action will follow when a professional organization declares itself on certain matters, courts are entitled to insist-under the "less-restrictive-alternative" requirement of the rule of reason ${ }^{95}$ - that collective speech take a form that minimizes the threat of such anticompetitive effects.

A conceivable issue of horizontal restraint might also arise if two or more professional organizations should agree to adopt and propagate a common view of a particular technology. Although there is no precedent for an antitrust attack on a naked conspiracy to eliminate competition in the formulation and expression of gratuitous opinions on commercially significant matters, the legal theory supporting such an attack would not be quite as far-fetched as one might expect. ${ }^{96}$ Admittedly, as public goods, the opinions offered are not typical articles of trade or commerce, to which the Sherman Act exclusively applies. Nevertheless, they are produced at some cost and have real commercial value to consumers and their agents. Most importantly, if the marketplace is to have access to a variety of views, it is essential that such opinions be produced under competitive rather than monopolistic conditions. Thus, if there were a shortage of other information and opinion and no efficiency justification for an agreement to speak with one voice (instead of independently), an antitrust court would probably advance consumer welfare by penalizing concerted action of this kind. Nevertheless, legal doubts and problems of proof-including the difficulty of showing in a specific case that two cooperating organizations had not arrived at their views independently and simply combined for efficiency reasons-probably eliminate any prospect for antitrust suits of this kind. Earlier discussion has shown, however, that, where feasible, remedies preserving or restoring competition in the production of information and opinions are preferable to regulation of the content of commercially significant speech. ${ }^{97}$

2. Vertical Restraints? Allegations of vertical restraints are also likely to complicate cases of this kind. ${ }^{98}$ Plaintiffs can be expected to contend that the

95. Where a joint venture of competitors would be valid because it contributes to efficiency, but the venturers possess power that poses a real danger to the maintenance of vigorous competition in the market as whole, "reasonableness" requires that the venturers achieve their legitimate purposes in ways that do not pose unnecessary hazards to competition. See, e.g., Silver v. New York Stock Exch., 373 U.S. 341 (1963) (holding that a lawful self-regulatory body was required under the antitrust laws to employ fair procedures to reduce the risk of anticompetitive abuse); United States v. Realty Multi-List, Inc., 629 F.2d 1351, $1369-87$ (5th Cir. 1980) (reviewing joint venture's membership requirements to ensure that they served legitimate needs and were no more restrictive than reasonably necessary to accomplish lawful purposes); United States v. Addyston Pipe \& Steel Corp., 85 F. 271 (6th Cir. 1898), aff'd, 175 U.S. 211 (1899) (ancillary restraints permissible only if reasonably necessary to achieve their legitimate object).

96. Cf. Havighurst \& King, supra note 49, at 295-300, 311-25. See infra note 124 .

97. See supra text accompanying notes 60-62 and 68-76.

98. The Schachar case did not involve such allegations, however. 870 F.2d at 398 ("Plaintiffs concede that the Academy did not attempt to coordinate activities with these groups, actors independent of the Academy."). 
defendants did not rely solely upon the persuasiveness of their representations but actually enlisted third party payers, hospitals, or others in a conspiracy depriving the plaintiffs of a fair opportunity to compete. A typical case would be colored by meetings and correspondence between the organized opponents of a new technology and health insurers or hospital medical staffs, following which the latter may have adopted largely uniform policies disadvantageous to those dealing in the questioned services. Courts faced with such allegations and facts must sort out the situation so that truly independent decisions by the entities solicited are identified and recognized for what they are-precisely the force that makes markets work, not suspicious circumstances requiring justification.

Unless a party standing in a vertical (noncompetitive) relationship to the contending practitioners can be shown to have acted against its own competitive self-interest in adopting the view being urged, any allegation of vertical conspiracy should fail:

To survive a motion for summary judgment or for a directed verdict, a plaintiff seeking damages for a violation of $\S 1$ must present evidence "that tends to exclude the possibility" that the alleged conspirators acted independently. [Plaintiffs], in other words, must show that the inference of conspiracy is reasonable in light of the competing inferences of independent action . . . .99

In one case, an organization of psychiatrists persuaded a physician-controlled Blue Shield plan to discriminate against the psychiatrists' competitors, clinical psychologists. The court rejected the allegation of a vertical conspiracy, however, stating that "it was not illegal for [the psychiatrist group] . . . to make recommendations aimed at persuading Blue Shield to adopt its proposal and use [its members'] services, absent some form of coercion." 100 Any other result in cases of this kind would interfere with legitimate efforts to compete by attempting to persuade relevant decisionmakers of the relative merits of the services being offered.

More serious allegations of vertical restraint would focus on the possibility that a professional group brokered a horizontal conspiracy against the plaintiffs among their customers or suppliers-or, in these cases, among third-party payers. As noted earlier, a herd instinct may exist among health insurers, who are anxious to be told how to regard a particular technology and to be relieved of the competitive responsibility to make independent judgments or to put the difficult choice to their customers, such as employers and employment groups. There may therefore be some risk that a professional organization could orchestrate a common response to a new

99. Matsushita Elec. Industrial Co. v. Zenith Radio Corp., 475 U.S. 574, 588 (1986), quoting Monsanto Co. v. Spray-Rite Service Corp., 465 U.S. 752, 764 (1984). See also Business Electronics Corp. v. Sharp Electronics Corp., $108 \mathrm{~S}$. Ct. 1515 (1988). It seems probable under these holdings that an insurer could refute an inference of conspiracy based upon its compliance with the professional organization's recommendation by showing potential cost savings that provided an independent motive for its action.

100. Virginia Academy of Clinical Psychologists v. Blue Shield of Va., 624 F.2d 476, 483 (4th Cir. 1980). 
technology by carrying messages back and forth among decisionmakers, ${ }^{101}$ playing upon their reluctance to take an independent position and their eagerness to act as their competitors do. ${ }^{102}$

A professional organization wishing to avoid exposure to a charge of aiding, abetting, and participating in collusion among insurers or others with respect to a new technology could protect itself by exercising care in the manner in which it urges its position. Perhaps the wisest course would be to avoid dealing directly with insurer trade associations. It should also make certain that it does not become a channel of communication among competitors seeking to conform their conduct to that of others. Once again, by inducing collaborators to adopt "less restrictive alternatives," 103 antitrust law can reduce real threats to competition without chilling activities that are truly procompetitive.

\section{IV}

\section{Antitrust Issues in Clinical Trials}

A professional organization that organizes a clinical trial of an emerging or existing technology might contribute important new scientific learning but interfere substantially with competition in so doing. Indeed, it would be difficult, if not impossible, to organize and design a scientifically valid trial without significantly infringing upon both the competitive freedom of the participating physicians and consumer sovereignty. Consider, for example, the efforts that might be necessary to induce a sufficient number of physicians to participate. Believing that the evidence did not yet warrant routinely prescribing a new procedure or other technology, the organization might declare it unethical for a practitioner to employ it except in the context of the trial. Although such an edict would be helpful in getting physicians to take part, the underlying agreement by the members to limit their competitive independence would clearly restrain trade, thus raising the question whether such restraints are excusable because they are ancillary to a joint venture to create new knowledge.

101. See supra note 92. For a leading case in which communication through an intermediary supported an inference of conspiracy, see Interstate Circuit, Inc. v. United States, 306 U.S. 208 (1939).

102. The radial keratotomy cases disclosed the existence of a formal program whereby the Council of Medical Specialty Societies, of which the AAO was member, routinely advised the Health Insurance Association of America (HIAA) of the status of new technologies. When radial keratotomy was declared experimental by the AAO, it was listed in an HIAA newsletter under the heading "Procedures Which Should Not be Reimbursed Routinely by Third Party Payers Without Written Justification." Schachar, 1988-1 Trade Cas. at 58,051. The HIAA was not a defendant in the cases, however, even though its activities facilitated a uniform response by payers to the AAO's recommendation. Nevertheless, the strongest evidence against the professional defendants, including the AAO, appeared to be their assistance to the HIAA in organizing a true insurer boycott of radial keratotomy. See supra text accompanying notes 51-56. Neither the complaints nor the courts' opinions, however, characterized the AAO's conduct in these terms.

103. See supra note 95. 
The rules governing the conduct of the trial itself are also likely to impair the process of decentralized decisionmaking. Although patients are free not to participate in the trial (their "informed consent" is necessary ${ }^{104}$ ), there may be no other way for them to obtain the new treatment from a reputable practitioner, in a good hospital, or at a third party's expense. Moreover, participation in the trial is no guarantee that the patient will get access to the procedure, because a proper trial requires a control group, whose experience will be compared with outcomes using the new technology. In general, the scientists' need to ensure randomness in the choice of treatment, blindness or double-blindness concerning the patient's actual status in the trial, and the statistical significance of the cumulative results makes it certain that consumer choice will be systematically denied, with sometimes troubling results. ${ }^{105}$ Indeed, it would be hard to visualize a more complete stifling of competitive independence and consumer choice than occurs in a well-designed clinical trial. ${ }^{106}$ An antitrust court would be hard pressed, under antitrust doctrine, to avoid condemning what may well be a sincere and socially useful effort to improve understanding of an important subject.

One of the peculiarities of antitrust law is that courts and commentators persist in formulating the legal test for evaluating concerted action under section 1 of the Sherman Act as being whether trade is "unreasonably" restrained, even though the statute clearly states that "every" restraint is prohibited. As every student of antitrust law knows, the early courts grappled with this problem of statutory construction and resolved it by adopting the rule of reason. ${ }^{107}$ Every serious student also knows that the rule of reason does not allow trade to be restrained whenever it is deemed reasonable as a policy matter to set competition aside-that is, whenever the defendants can demonstrate that they were motivated by a socially worthy purpose. ${ }^{108}$ Instead, the rule of reason means only that the court should not jump to the conclusion that every agreement restricting competition between independent entities is necessarily prohibited. Reason should be exercised to determine whether the particular concerted action is compatible with the maintenance of competition as society's chosen mechanism for allocating resources. Competitor collaboration should therefore be judged to restrain

104. See generally J. Katz, Experimentation with Human Beings 523-724 (1972).

105. For example, even though evidence might begin to accumulate against a particular method of treatment, the study should not be stopped until there is enough data to give statistical validity to the study's ultimate results; some patients will therefore still be treated with the apparently inferior technology until the scientists declare the trial over. On the ethics of this dilemma, see Freedman, Equipoise and the Ethics of Clinical Research, 317 NEw ENG. J. MED. 141, 141-42 (1987) (citing other discussions).

106. Although the infringements on provider and patient freedom inherent in clinical trials may be viewed (as here) in antitrust terms, they are ordinarily addressed as ethical problems. See, e.g., C. Fried, Medical Experimentation: Personal Integrity and Social Policy 29-36 (1974); Freedman, supra note 105 (arguing that a physician should suppress his ethical qualms about participating in a trial in the presence of uncertainty in the medical community).

107. See infra note 122.

108. National Soc'y of Prof. Eng'rs v. United States, 435 U.S. 679, 691 (1978). See also infra note 115. 
trade only if it reduces the vigor of competition in some market to such an extent that, despite the collaboration's arguable benefits to competition and to consumer welfare, consumers would be worse off if it were allowed. The Supreme Court has formulated the test for reasonableness as being "whether the challenged agreement is one that promotes or one that suppresses competition." 109

The problem examined here is made especially difficult by the failure of commentators, lawyers, and courts to view the collective production of information and informed opinion as they would view a joint venture to produce material goods or services that could not be produced at all, or produced as efficiently, in the absence of competitor collaboration. Concerted action to produce a public good should, it would seem, qualify presumptively as a highly procompetitive undertaking. Nevertheless, because a verdict of procompetitiveness would rest upon the presumed benefits of the information to competition in a market separate from the market for information itself-that for the technology in question-the analysis cannot stop simply with the observation that a new and presumably valuable product is being produced. Instead, there must be some balancing of benefits to competition against potential harms to it.

Potential harm to competition is in part a function of the market power that the collaborators might wield if they should choose to abuse their position. A professional organization representing the majority of the practitioners in a specialty field would seem to have such power. Nevertheless, it would be relevant to consider whether there is a fringe group of competitors-nonmembers or mavericks within the organization-who might provide the questioned service to those patients who, after being fully informed, really wanted it and were fearful of participating in the trial. Possession by the collaborators of any appreciable market power should, however, trigger a further inquiry into whether the joint venture had been designed to eliminate no more competition than was necessary to achieve its procompetitive object. Indeed, real help in resolving the problem at hand may be found in the rule of reason's requirement that collaborators who are in a position to harm the competitive process must achieve their legitimate purposes by adopting a "less restrictive alternative" ("LRA") if one is reasonably available. ${ }^{110}$ Thus, if the procompetitive purpose being pursued truly requires a particular restriction of the parties' competitive freedom, the restriction should not be condemned without balancing the projected benefits of the collaboration to the competitive process and consumer welfare against the harm to consumers that might be expected to ensue from the restrictions themselves. Application of this test to profession-sponsored clinical trials should lead a court to examine the scientific merits of the study's design and the social importance of the problem being studied. Under such an analysis, a

109. Id.

110. See supra note 95 . 
well-designed study aimed at eliciting important, efficiency-enhancing information might well be permitted to proceed.

A good clinical study requires large numbers of participating patients, thus suggesting that efforts to enlist practitioners serve a procompetitive purpose. Under the LRA requirement, coercion would not be an appropriate way to enlist participation, but an opinion as to the importance of the trial that was couched in ethical terms might not seem out of order if it was accompanied by a disavowal of any intent to impose sanctions. ${ }^{111}$ The rules for conducting the trial itself should be examined to see whether they are more restrictive than necessary to accomplish the alleged scientific purpose. By invoking the LRA requirement, an antitrust court might reinforce the legal and ethical requirement of informed consent, thus protecting the opportunity of consumer/patients to seek additional information and exercise choice.

Although the recommended analysis might cause an antitrust court to tolerate a network of quite severe restraints of trade, the LRA requirement would also impose a strict limit on the duration of the trial, thus ensuring that the professional group could not rig the market for an indefinite period. Once the information sought in the trial was obtained, the market would have to be allowed to return to its natural competitive state, thus mitigating the adverse effects of the restraints. Imposing a strict, scientifically determined time limit on the trial would ensure that its benefits are realized without more restraint of competitive forces than is truly necessary. Of course, if a professional group sought to establish a trial of indefinite duration ostensibly to examine long-term effects of the technology, the court would probably have to conclude that the harm to competition was too great and too longlasting in comparison with the benefits to be derived. Such trials could be carried out under other auspices or using other methods. It is often possible, for example, by relying on so-called natural experiments, to mount long-term studies without the rigorous restraints of a randomized trial. The law would appear to give consumers the benefit of competition while such studies are being conducted.

One question that has arisen in the radial keratotomy cases is whether government's participation in the design and financing of the trial confers any antitrust immunity upon the private proponents. Because Congress has not given its express blessing to anticompetitive arrangements of this kind if they are entered into under the oversight of government officials, the answer to this question is clearly that the antitrust laws continue to apply to government-financed or -sponsored studies by professional groups. ${ }^{12}$ The analysis offered here, however, would, if adopted, leave significant room for such studies because it visualizes that good scientific design, which

111. Of course, practitioners might be gun-shy about the possible liability risks they incur in not following standards of dominant medical groups. The legal system should therefore leave room for practitioners to depart from the dominant standard of care if they make adequate disclosure. See generally Havighurst, supra note $\mathbf{5 5}$.

112. This was the holding in Vest v. Waring, 565 F. Supp. 674 (N.D. Ga. 1983). 
government funding agencies presumably foster and to some extent guarantee, would be a good defense to an antitrust charge.

\section{Conclusion}

Antitrust law has been increasingly recognized in recent years as an undue constraint on collaboration among competitors, sometimes sacrificing efficiency and reducing consumer welfare. This article has offered legal, economic, and other reasons why antitrust courts should leave organizations of professional competitors free within a wide range to participate in debates concerning medical technologies. In addition to resolving questions surrounding a specific instance of competitor collaboration in the production and dissemination of scientific information and opinion, the article may also be read to throw some useful light on several general analytical issues regularly encountered in administering the antitrust laws. These concluding remarks attempt to draw some broader lessons from the foregoing analysis.

\section{A. Professionalism as an Antitrust Defense}

A question frequently encountered since active enforcement of the Sherman Act began in the medical care field in the mid-1970's is whether professional status might entitle defendants to special leniency before an antitrust court. Although the Supreme Court has held out in several cases the possibility that professionals, although not exempt from the antitrust laws, might be subject to softer antitrust rules than other tradesmen, it has yet to rule in favor of professionals on such a basis in any case. ${ }^{13}$ Medical technology assessment, however, might seem to be an appropriate occasion for explicitly recognizing the ethical concerns and public responsibilities that professionals are supposed to possess by relaxing the antitrust rules applicable to their collective activities. After all, physicians engaged in technology assessment are not acting to reduce competition among themselves. They are instead-on the face of it, at least-attempting to protect the public against untested medical procedures that overzealous or

113. Each of the Court's successive statements of its reservations about applying the antitrust laws to professionals has been narrower than the preceding one. See, e.g., United States v. Oregon State Medical Soc'y, 343 U.S. 326, 336 (1952); Goldfarb v. Virginia State Bar, 421 U.S. 773,788 n. 17 (1975); National Soc'y of Prof. Eng'rs v. United States, 435 U.S. 679, 696 (1978); Arizona v. Maricopa County Medical Soc'y, 457 U.S. 332, 348-49 (1982). In its most recent pronouncement, the Court, although acknowledging that "we have been slow to condemn rules adopted by professional associations as unreasonable per se," also said that application of the rule of reason to a concerted refusal by dentists to provide $x$-rays for their patients' dental insurers to use in cost containment was "not a matter of any great difficulty." FTC v. Indiana Fed'n of Dentists, 476 U.S. 477, 458 (1986). The Court specifically rejected the excuse that the dentists were motivated by professional concerns about the quality of care their patients would receive under the insurers' restrictions. In light of these precedents, it is no longer easy to argue that professionals qua professionals are entitled to especially lenient treatment under the antitrust laws. On the other hand, markets for professional services are unusual in some respects (see Professional Engineers, 421 U.S. at 696); thus, application of the rule of reason to protect both efficiency and competition in such markets may require special intellectual effort. 
unethical physicians might induce ignorant consumers to purchase. Perceiving this to be precisely the kind of consumer protection that society has long expected the medical profession to provide, many would approve an antitrust court that treated such activities with special deference-either as a legitimate exercise of professional prerogative ${ }^{114}$ or as a legitimate response to a recognized imperfection (consumer ignorance) in the market for professional services. 115

The antitrust defense of medical technology assessment in this articlelike that in the Schachar case, the only legal authority directly on point-does not depend at all upon the professionalism or allegedly noncommercial motives of the physician organizations engaged therein. Adhering to the wellestablished but frequently neglected view that a worthy social purpose cannot redeem a restraint of trade, ${ }^{116}$ this article argues that the collective activities surveyed can be justified on other grounds-specifically, their procompetitiveness and fundamental consistency with the competitive process. Thus, this article demonstrates that standard antitrust doctrine is quite capable of reaching a sensible result without carving out a special exception for an elite class of defendants. ${ }^{17}$

114. In Wilk v. AMA, 719 F.2d 207 (7th Cir. 1983), cert. denied, 467 U.S. 1210 (1984), a court of appeals recognized a peculiar kind of limited professionalism defense for a naked physician conspiracy to boycott chiropractors. Any professional prerogative to take otherwise prohibited collective action in patients' interests was rather clearly negated, however, by the Supreme Court's opinion in Indiana Federation of Dentists, 476 U.S. 477 (1986).

115. Because courts have never held that all naked restraints-that is, all restraints whose object contemplates reducing the general vigor or narrowing the scope of competition-are illegal per se, some principled doctrinal basis on which some such restraints can be upheld must be identified. Courts have tended only to speak vaguely of "reasonableness," "noncommercial purpose," or the necessity for specific "anticompetitive intent"-formulations that fly in the face of the statute, which is concerned only with effects on competition. In theory, however, a restraint intended and designed only to overcome the effects of consumer ignorance (a particular problem with professional services) or some other certifiable (and serious) market failure could be viewed, without incoherence, as a procompetitive undertaking not out of keeping with the competitive paradigm upon which antitrust policy is founded. Thus, a sincere effort by competitors to make an imperfect market yield results closer to those of an efficient market might be tolerated precisely because it would not constitute, on its face, "a frontal assault on the basic policy of the Sherman Act." National Soc 'y of Prof. Eng 'rs, 435 U.S. at 695 .

Obviously, a court should be highly skeptical of any competitor group's claim that its only object is to strengthen competition and benefit consumers. Indeed, the implausibility of such claims and the rarity of cases in which they would be accepted might seem to justify ignoring the possibility of redemption and declaring all naked restraints unlawful. Cf. supra note 82. There is a good pragmatic reason, however, why antitrust law should keep narrow defenses of this kind available in theory even if they are rarely recognized in practice: Antitrust policy would be less credible politically if it appeared to embody an ideology that was impervious to the fact that competition does not always work in accordance with textbook theories or in the overall public interest. Thus, if antitrust enforcers refused even to listen to such arguments (on the ground that the statute requires competition for better or for worse), affected groups, especially influential professional ones, might find it much easier to appeal to legislatures for antitrust exemptions and other relief from alleged persecution by hidebound free-marketeers. See Havighurst \& King, supra note 49, at 296-98, 280 n.51.

116. See supra text accompanying note 108 .

117. The court of appeals in Schachar did not even allude to possible defenses based on the defendants' professional status. Its statement that the status of radial keratotomy "is a medical rather than a legal question," was offered not to suggest a special prerogative but in response to the plaintiffs" claim that a professional organization has a special "obligation to the public." $870 \mathrm{~F} .2 \mathrm{~d}$ at 
It would be a distinct service to the integrity of antitrust doctrine if courts would likewise eschew analyzing the collective actions of physicians as a special category of restraints and concentrate on developing all-purpose tools for distinguishing between anticompetitive and procompetitive collaboration. If it seems necessary to bend established principles in order to reach a procompetitive, efficiency-enhancing result in an antitrust case, then those principles should be reexamined and reshaped so that they serve the statutory objective of enhancing consumer welfare. If, on the other hand, the reason being urged for departing from standard doctrine is simply a felt need to exempt doctors from the rules of free enterprise in order to realize an allegedly greater good, then the courts, which lack statutory authority to engage in such policy making, should refuse to go along. Explicitly treating professionals as no less likely than the rest of us to combine to pursue economic self-interest would not only force courts to increase the rigor of their antitrust analysis but also complete what is proving to be a healthy procompetitive revolution in American health care.

\section{B. Protecting Competition, Not Competitors}

A professional group's expression of an influential opinion concerning a particular medical technology presents another problem commonly encountered in antitrust analysis-namely, that of distinguishing collaboration that jeopardizes consumer welfare, as served by the maintenance of competitive markets, from joint conduct that affects adversely only the welfare of certain competitors. ${ }^{118} \mathrm{~A}$ danger in the administration of the antitrust laws is that sympathy for a disadvantaged competitor or distrust of powerful defendants may lead judges to equate loss of a competitor with harm to competition. They may thus view their function as being to referee the competitive contest, enforcing some standard of fairness against those who are perceived to be in a position unfairly to dominate the market-or, in the case of technology assessment, to prejudice it against certain goods or services. Such refereeing could easily convert antitrust law from being an instrument for maintaining healthy competitive conditions in the interest of consumers into a tool for policing unfair competition primarily in the interest of competitors.

400. For a series of articles arguing that other professional activities can likewise be analyzed sensibly under the antitrust laws without reference to the professional status of the defendants, see Havighurst, supra note 28; Havighurst, supra note 64; Havighurst \& King, supra note 49; Havighurst, supra note 27. (The latter two articles develop theses-principally the argument that professional groups that engage only in the production of information should be subject to no more than a "quick look" under the rule of reason-that are similar to the ones in this article.) Use by antitrust courts of artificial distinctions and exceptions as narrow grounds for saving certain types of legitimate concerted action can be doctrinally destructive, especially where, as here, that decisional strategy seems to confirm that general antitrust principles would otherwise condemn efficiency-enhancing collaboration.

118. It is frequently stated that antitrust law is intended to protect "competition, not competitors." E.g., Brunswick Corp. v. Pueblo Bowl-O-Mat, Inc., 429 U.S. 477, 488 (1977), citing Brown Shoe Co. v. United States, 370 U.S. 294, 320 (1962). 
Antitrust law should serve functional, efficiency-enhancing purposes and not just provide opportunities for indulging regulatory impulses or for cathartic bashing of the rich and powerful. Past attempts to shape antitrust doctrine to advance policy goals other than the maintenance of competitive conditions have contributed to incoherence, inconsistency, and unpredictability in the law, raising litigation risks and costs, discouraging the singleminded pursuit of efficiency, and protecting the inefficient. ${ }^{119}$ The Sherman Act should thus be read to embody the presumption that consumers are better served in the long run by a rough-and-tumble competitive struggle than by judicial regulation of competitive behavior. Antitrust relief should therefore be denied to competitors whose true complaint is simply about the rigors of competing in a hotly contested market.

Reduced to these essentials, the issues examined in this article resemble those underlying the ongoing ideological struggle for the soul of antitrust law. In that struggle, adherents of the so-called Chicago School, reading the law as embodying a consumer-oriented policy with efficiency as the exclusive criterion, ${ }^{120}$ vie with those who view antitrust law as also incorporating a concern for fairness and populistic political values, even at some cost to the consumer. ${ }^{121}$ Although Judge Easterbrook's Chicago-style opinion in Schachar will be persuasive to many, the battle to discourage judges from regulating competitive behavior and reversing the sometimes harsh

119. This is essentially the charge leveled by the Chicago critics. See infra note 120. See also Arthur, Workable Antitrust Law: The Statutory Approach to Antitrust, 62 TuL. L. REv. 1163, 1167-70, 1191 1213 (1988).

120. See generally R. Bork, The Antitrust Paradox: A Policy at War with Itself 81-89 (1978); R. Posner, Antitrust Law: An Economic Perspective 8-22 (1976); Posner, The Chicago School of Antitust Analysis, 127 U. PA. L. Rev. 925 (1979). Judge Easterbrook's expositions of the Chicago thesis are cited supra in note 14. The Supreme Court appeared to move in the direction of the Chicago position in Continental T.V. v. GTE Sylvania, 433 U.S. 36 (1977). Rejecting concern about dealer independence as a basis for challenging a vertical restraint, the Court said, "[c]ompetitive economies have social and political as well as economic advantages, . . but an antitrust policy divorced from market considerations would lack any objective benchmarks." Id. at 53 n.21.

121. A good recent overview of the policy debate, citing and summarizing numerous authorities (including such critics of the Chicago school as Professors Fox, Hovenkamp, and Kaplow), appears in Arthur, supra note 119, at 1201-13. Professor Arthur argues that the warring camps adopt an erroneous "constitutional" view of antitrust, under which the statutes are interpreted simply as a delegation by Congress of policymaking responsibilities to the courts. The policy debate is thus fated to go on indefinitely and inconclusively, says Professor Arthur, as judges and scholars give range to their divergent political philosophies, balancing the competing values differently and producing incoherent law. Professor Arthur argues convincingly that the public interest in making antitrust law predictable would be better served by an alternative "statutory approach," which would focus exclusively on whether the defendants have interfered with the competitive process.

Although the present article follows the usual Chicago School approach in arguing that economic efficiency and the broad public interest are truly served by competitor collaboration in the provision of information, it essentially employs the statutory approach in its bottom-line conclusions. Similarly, Judge Easterbrook's opinion in Schachar appears also to turn less on policy than on a strict construction of the statute, thus possibly avoiding Professor Arthur's strictures. In general, Professor Arthur's campaign to return antitrust law to a search for the specific meaning of statutes seems a helpful prescription. On the construction of section 1 of the Sherman Act, compare the four-step methodology in Arthur, Farewell to the Sea of Doubl: Jettisoning the Constitutional Sherman Act, 74 Calif. L. Rev. 263, 334-47 (1986), with C. Havighurst, supra note 54, at 325-30 (note on the rule of reason). 
judgments of the marketplace is far from over. The case of professionsponsored technology assessment may nevertheless serve to illustrate the foolishness of trying to referee the competitive contest and the wisdom of letting the competitive process play itself out, without appeal.

\section{Identifying and Analyzing "Ancillary" Restraints}

Yet another familiar problem of antitrust analysis would be presented by a professional group's conduct of a rigorous clinical trial of a new or existing technology. The court's task in such a case is to determine whether the restraints imposed on the competitive independence of the physicians participating in the trial and the limitations necessarily imposed on consumer sovereignty were justified by the larger objective of eliciting valuable information. Courts have frequently encountered difficulty in knowing when obvious and substantial restrictions should be condemned as per se violations of the antitrust laws-that is, without regard to their specific effects or the particular circumstances. The alternative approach is to judge the specific restrictions in light of their actual or probable net effect on competition and consumer welfare. The problem of distinguishing so-called "ancillary" restraints from "naked" ones, which ordinarily cannot be redeemed by any justification, has existed since the earliest days of antitrust enforcement. ${ }^{122}$ Nevertheless, courts still struggle with it. ${ }^{123}$

A clinical trial organized by a physician organization would present the issue here in a particularly stark form because the restraints involved would be numerous and of the severe sort that usually qualify for per se treatment. Nevertheless, there is no reason why even severe restraints imposed by a powerful professional group cannot be justified under the ancillarity principle if all the conditions-especially the less-restrictive-alternative requirementare met. As argued earlier, the features that might redeem a clinical trial are, first, its procompetitive informational objective, which must be borne out in both the competitors' overall conduct and the trial's design, and, second, its limited duration, which could make even very severe restraints tolerable in

122. E.g., Standard Oil Co. v. United States, 221 U.S. 1, 60-68 (1911); United States v. Addyston Pipe \& Steel Co., 85 F. 271 (6th Cir. 1898), aff' $d$, 175 U.S. 211 (1899).

123. Perhaps the Supreme Court's worst effort in this field was United States v. Topco Assocs., 405 U.S. 596 (1972) (condemning under per se rule a horizontal market-division arrangement clearly necessary to effectuate a procompetitive joint venture). For a wiser opinion on a similarly procompetitive arrangement, see Rothery Storage \& Van Co. v. Atlas Van Lines, Inc., 792 F.2d 210 (D.C. Cir. 1986) (Bork, J.). A series of opinions written for the Court by Justice Stevens further illustrates the difficulties: National Soc'y of Prof. Eng'rs v. United States, 435 U.S. 679 (1978) (clarifying that a naked restraint cannot be redeemed by demonstrating that competition was infringed for a worthy social purpose); Arizona v. Maricopa County Medical Soc'y, 457 U.S. 332 (1982) (stating that the Court was bound to apply a per se rule by its own prior precedent, but actually taking a "quick look" under the rule of reason to establish that the arrangement was not likely to be procompetitive in fact); NCAA v. Board of Regents, 468 U.S. 85 (1984) (ostensibly eschewing application of a per se rule, but then proceeding only to demonstrate that the restraint was naked and lacked any procompetitive virtue and therefore warranted condemnation without proof of market power- (hat is, per se treatment). Only the most careful reading of the latter two opinions, ignoring what Justice Stevens said he was doing and focusing on what he actually did, makes them sensible applications of the rule of reason. 
light of the benefits soon to be derived. If antitrust courts, laboring under misguided precedent, cannot bring themselves to excuse incidental restraints that serve a larger procompetitive purpose, legislative relief might be in order. Given the difficulty of getting Congress to write an appropriately limited exemption, however, one should hope that the problem can be obviated by judicial adjustments of received doctrine.

\section{Antitrust Law and Information}

A final general issue addressed in this article is the antitrust significance of information produced and disseminated by organized competitors. Legal appraisals of efforts by influential competitor groups to compete by informational means must reflect a sophisticated understanding of the competitive process and how it can be impaired not only by competitors conspiring to exclude their rivals but also by antitrust courts engaged in overregulation. This article has demonstrated the importance of information and opinion in the operation of the market for health services and has called attention to the workings of the market for information itself. Because information is a public good that tends to be underproduced by disinterested private producers, the consuming public is dependent for vital information upon competitors' representations. Although the impulse to use the antitrust laws to regulate the quality and content of the information thus produced may sometimes be very strong, antitrust law provides only a very limited warrant, if any at all, for judicial intervention.

Economic markets may also be marketplaces of ideas and informationvital forums in which scientific and technical theories compete, empirical data are adduced, and decisions are made and remade on the basis of accumulating evidence. The medical context examined in this article provides an excellent opportunity to recognize the kinship between the dynamic competitive process that the antitrust laws are designed to protect and the marketplace of ideas protected by the first amendment. Antitrust law, this article has argued, should be enforced with a view to maintaining the robustness of the entire competitive process, including competition in the realm of scientific opinion and information. Information is power. More information from more sources-that is, competition in the scientific and ideological marketplace-is liberating and provides the best answer to those who would propagate untruths or half truths. If antitrust law is to be applied at all to the market for information and opinion, it should be used, not to regulate what may be produced, but to prevent actual or potential competitors in that market from combining or conspiring to restrict the output of data or the diversity of views expressed. ${ }^{124}$

124. See supra text accompanying notes 96,97 . For an unconventional proposal to focus antitrust law on protecting competition in a unique "relevant market"- that for information and opinion concerning commercial goods and services - see part two of Havighurst \& King, supra note 49, which seeks to demonstrate: 
the unlawfulness of certain hitherto unquestioned relationships among independent entities actually or potentially engaged in producing valuable consumer information. The key to the analysis-and the shortest and surest path to sensible legal results-is recognition that a market for commercially valuable information and opinion exists and can be kept competitive by applying traditional antitrust principles to those participating in it. Aside from the straightforward observation that consumer information is itself a product that should be produced under competitive conditions and whose output is subject to destructive trade restraints amenable to scrutiny under the Sherman Act, the analysis does not depart from the antitrust mainstream. Id. at 334 . 
